\title{
Effect of Nanofluids on the Enhancement of Boiling Heat Transfer: A Review
}

\author{
Md. Osman Ali, Mohammad Zoynal Abedin, Md. Dulal Ali and Mohammad Rasel
}

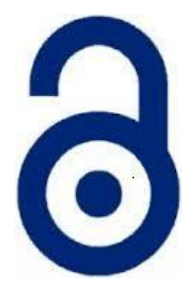

Received: 15 April 2021

Accepted: 29 April 2021

Published: 01 October 2021

Publisher: Deer Hill Publications

(C) 2021 The Author(s)

Creative Commons: CC BY 4.0

\begin{abstract}
Boiling heat transfer can play a vital role in the two-phase flow applications. The analysis of the boiling hat transfer enhancement is of importance in such applications and the enhancement can be mostly conducted by using various active and passive techniques. One type of passive techniques is the enhancement of heat transfer by nanofluids. This article presents an extensive review on the effect of different nanofluids on the enhancement of heat transfer coefficient (HTC) and critical heat flux (CHF) for both pool as well as flow boiling. Nanoparticles addition to a working fluid is done arbitrarily to improve the thermophysical properties which in turn improves heat transfer rate. Numerous works have been done in the studies on nanofluid boiling. Among various nanoparticles, the most frequently used nanoparticles are $\mathrm{Al}_{2} \mathrm{O}_{3}$ and $\mathrm{TiO}_{2}$. In the case of binary nanoparticles, the most commonly used combination is $\mathrm{Al}_{2} \mathrm{O}_{3}$ and $\mathrm{TiO}_{2}$. After reviewing the relevant literatures, it is found that for pool boiling, the maximum $\mathrm{HTC}$ is increased to $138 \%$ for $\mathrm{TiO}_{2}$ nanoparticles and the maximum CHF is increased to $274.2 \%$ for MWCNTs. Conversely, in flow boiling the maximum HTC is increased to $126 \%$ for $\mathrm{ZnO}$ nanoparticles and the maximum $\mathrm{CHF}$ increased to as $100 \%$ for $\mathrm{CO}$ nanoparticles. In addition, when two or more nanoparticles in succession or binary nanofluids are used the $\mathrm{CHF}$ in pool boiling increased up to $100 \%$ for $\mathrm{Al}_{2} \mathrm{O}_{3}$ and $\mathrm{TiO}_{2}$ as well as the $\mathrm{CHF}$ in flow boiling increased up to $100 \%$ for $\mathrm{Al}_{2} \mathrm{O}_{3}, \mathrm{ZnO}$, and Diamond. Though the information of the coefficient of heat transfer and the critical heat flux varied for different nanofluids and vary from experiment to experiment for each of the nanofluids. This variation happens because the coefficient of heat transfer and the critical heat flux in boiling is dependent upon several factors.
\end{abstract}

Keywords: Boiling, Nanofluids, Nanoparticle, Heat transfer coefficient, Critical heat flux.

$\begin{array}{ll}\text { ABBREVIATIONS } & \\ \text { HTC } & \text { Heat Transfer Coefficients } \\ \text { CHF } & \text { Critical Heat Flux } \\ \text { BHT } & \text { Boiling Heat Transfer } \\ \text { PBHT } & \text { Pool Boiling Heat Transfer } \\ \text { Nu } & \text { Nusselt Number } \\ \text { Re } & \text { Reynolds Number } \\ \text { HFP } & \text { Heat Flux Partitioning } \\ \text { NPs } & \text { Nanoparticles } \\ \text { h-BN } & \text { Hexagonal boron nitride } \\ \text { CNs } & \text { Carbon Nanotubes } \\ \text { MWCNs } & \text { Multi Walled Carbon Nanotubes } \\ \text { THE } & \text { Heat Transfer Enhancement } \\ \text { HF } & \text { Heat Flux } \\ \text { CMC } & \text { Carboxyl Methyl Cellulose } \\ \text { GO } & \text { Graphene-oxide } \\ \text { CFD } & \text { Computational fluid dynamics } \\ \text { DCM } & \text { Dichloromethane }\end{array}$

Ali, M. O., Abedin, M. Z. 区, Ali, M. D. and Rasel, M.

Department of Mechanical Engineering

Dhaka University of Engineering and Technology

Gazipur 1707, Bangladesh

E-mail: abedin.mzoynal@duet.ac.bd

Reference: Ali et al. (2021). Effect of Nanofluids on the Enhancement of Boiling Heat Transfer: A Review. International Journal of Engineering Materials and Manufacture, 6(4), 259-283. 


\section{NTRODUCTION \\ 1.1 Background}

Boiling is a type of convective heat transfer characterized by high heat fluxes, which are usually experienced in many engineering applications such as cooling of nuclear reactors, cooling of high-power electronics components, heat exchangers. The industrial world essentially relies on the massive use of fossil fuels to solve many negative problems, such as decreasing energy sources and triggering global warming, which is believed to be the primary cause of climate change. As a result, the advancement of energy conservation and environmental safety have become critical criteria for the planet. The performance of numerous engineering applications, such as boilers in energy generation, cooling in refrigeration systems, and many heat exchangers for various uses, is one of the significant methods of mitigating the influence of global heating. Mostly, all of these heat exchangers are processed by boiling heat transfer. Thus, considerable study and consideration have to be given to boiling phenomena [1].

\subsection{Enhancement Techniques}

Enhancement techniques of boiling heat transfer are two types: passive and active enhancement techniques. Nanofluids heat transfer enhancement is one kind of passive techniques. An external source of power is not needed by passive techniques. Extended surfaces, rough surfaces, improved surfaces, gas additives, liquid additives, swirl flow devices, coiled tubes, surface tension devices, micro/nanostructured surfaces, nanofluids, magnetically actuated nanofluids, electrophoretic deposition of $\mathrm{SiO}_{2}$ nanofluid, micro-machined porous channels and displaced enhancement devices are the examples of passive techniques. Then again, for active techniques, exterior power is essential. They include fluid vibration, electric or magnetic jet impingement fields, surface vibration, mechanical aids, injection or suction, and techniques of compounding. In this analysis, attention will be paid to the accumulation of nanofluids to the base fluid to boost the transfer of boiling heat.

\subsection{Nanofluids}

Nanofluids are tiny particle-size and lower concentrated nanoparticle suspensions distributed in base fluids like as water, oil, pentane, and ethylene glycol. Due to their thermophysical characteristics and a wide quantity of possible conveniences in conventional thermal engineering applications, such as energy production, transport, air conditioning, electronic devices, and cooling systems, researchers found these fluids as a special heat transfer transporter. Nanofluids are suspensions of solid particles of nanometre size and different chemistries (metals, metals, cooling systems). It can also be characterized as a mixture of solids and liquids consisting of nanoparticles and a base liquid.

Examples of such nanoparticles are $\mathrm{Al}_{2} \mathrm{O}_{3}, \mathrm{SiO}_{2}, \mathrm{TiO}_{2}, \mathrm{SiC}, \mathrm{Bi}_{2} \mathrm{O}_{3}, \mathrm{GO}, \mathrm{CuO}, \mathrm{CuO}_{2}, \mathrm{ZnO}, \mathrm{Fe}_{3} \mathrm{O}_{4}, \mathrm{Fe}_{2} \mathrm{O}_{3}, \mathrm{ZrO}_{2}$, $\mathrm{Cr}_{2} \mathrm{O}_{3}, \mathrm{CaO}, \mathrm{WO}_{3}$, and $\mathrm{MgO}$. Other highly used nanoparticles are Au, CNs, MWNTs, Ceramic, Diamond, AIN and Copper. Researchers have investigated the boiling enhancement with the above nanoparticles. There is only low thermal conductivity in the traditional base fluid.

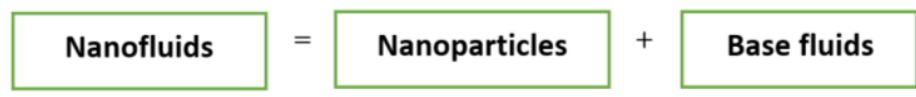

\subsection{Current Situation of The Study of Nanofluids}

Nanofluids can be measured as heat transfer fluids of the next generation because they suggest exciting options to increase the efficiency of heat transfer as compared to pure liquids. The growth of publications on nanoparticles research is shown in figure 1. Different researchers have shown that, compared to their base fluids, nanofluids provide improved heat transfer. It can be the motivating force for research to perform and eventually replace traditional functioning fluids. It was seen that arbitrary movement (Brownian movement) of nanoparticles and thermophoresis expand the energy transport performance. However, there are major problems such as erosion, clustering, sedimentation, and precipitation related to the use of nanofluids as the operating fluid. The influence on nanoparticle stability of changes in nanoparticle surface topology has also been well documented in the literature. In various experiments, nanofluids have been used to increase heat transfer in both single and two-phase systems. The findings of the earlier experiments indubitably indicate that with forced convection, nanofluids provide excellent heat transfer enhancement. In contrast, the normal convection and boiling of nanofluids in the literature has led to some contradictory findings [2]. 


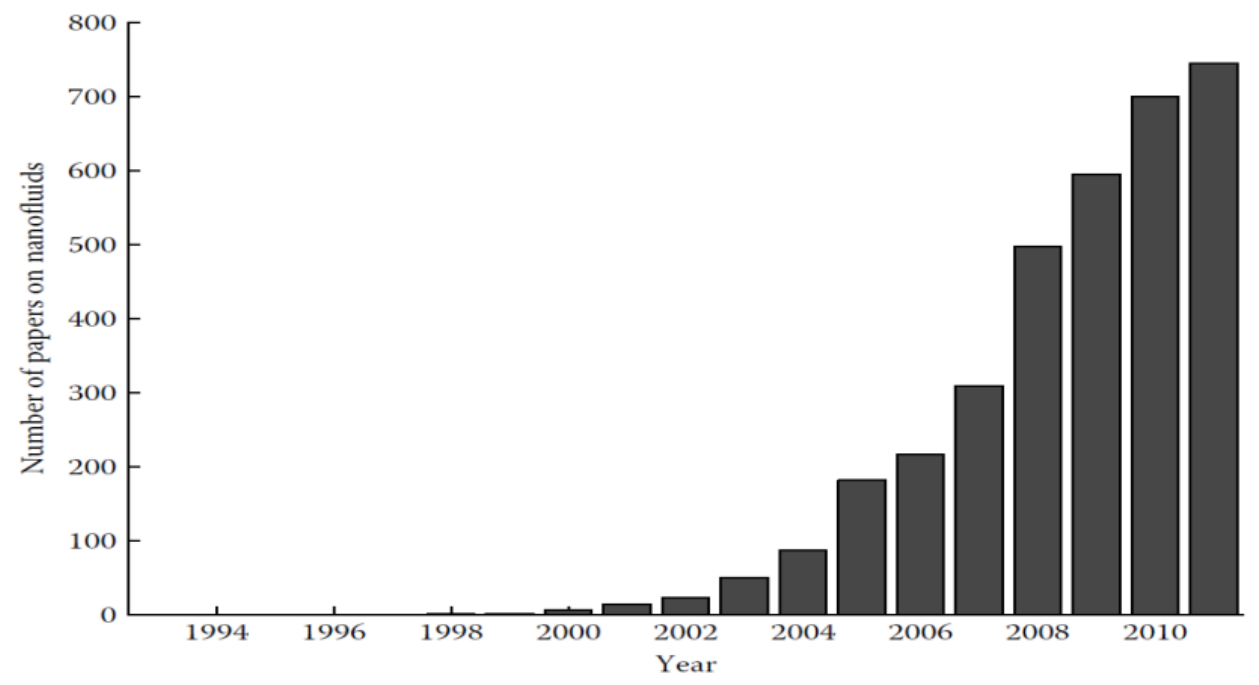

Figure 1: Growth of publications on nanofluids [3]

\section{BOILING HEAT TRANSFER}

A convection heat transfer process including a change in phase from liquid to vapour is referred to as boiling. It can also be defined as the change of phase from liquid to vapour at liquid vapour. Actually, boiling is a convective heat transfer process that includes phase change at a constant temperature from liquid to vapour [4]. During the boiling, the heat added to liquid for its phase change is the latent heat. Sometimes, the boiling process is also referred to as vaporization, when the latent heat of liquid is provided for its phase change such as the process of steam generation in the boiler. Boiling is also a mode of heat transfer that involves the creation of vapour bubbles at the solid-liquid boundary. The growth of vapour and its dynamics depend on temperature excess, nature of the surface and thermophysical properties of the liquid, such as its surface tension, latent heat, etc. Thus, the boiling may occur under various conditions. Based on the presence of bulk fluid motion [5], various modes of boiling are (i) pool boiling and (ii) flow boiling. Pool boiling refers to a situation of boiling in which the heated surface is immersed below the free surface of a stationary liquid and its motion adjacent the surface because of the natural convection only and the combination is made by bubble development and its separation [4]. Flow boiling refers to a situation of boiling, in which the fluid motion is induced artificially by an external means as well as by natural convection and the bubble induced mixing. This type of boiling takes place in high-pressure water tube boilers involving forced convection [5]. The schematic of the above-described types of boiling can be given by figure 2. Figure 3 shows the conventional pool boiling curve of water at atmospheric pressure and the schematic of each regime of it.

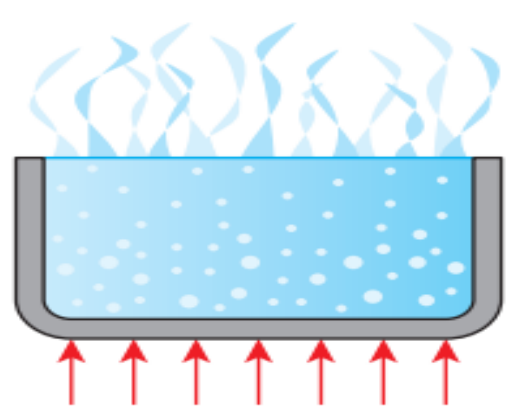

Heating

(a) Pool boiling

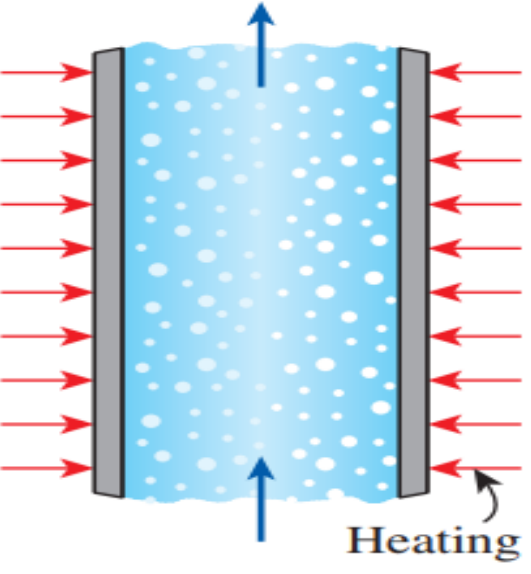

(b) Flow boiling

Figure 2: Types of boiling on the basis of the presence of bulk fluid motion [5]. 


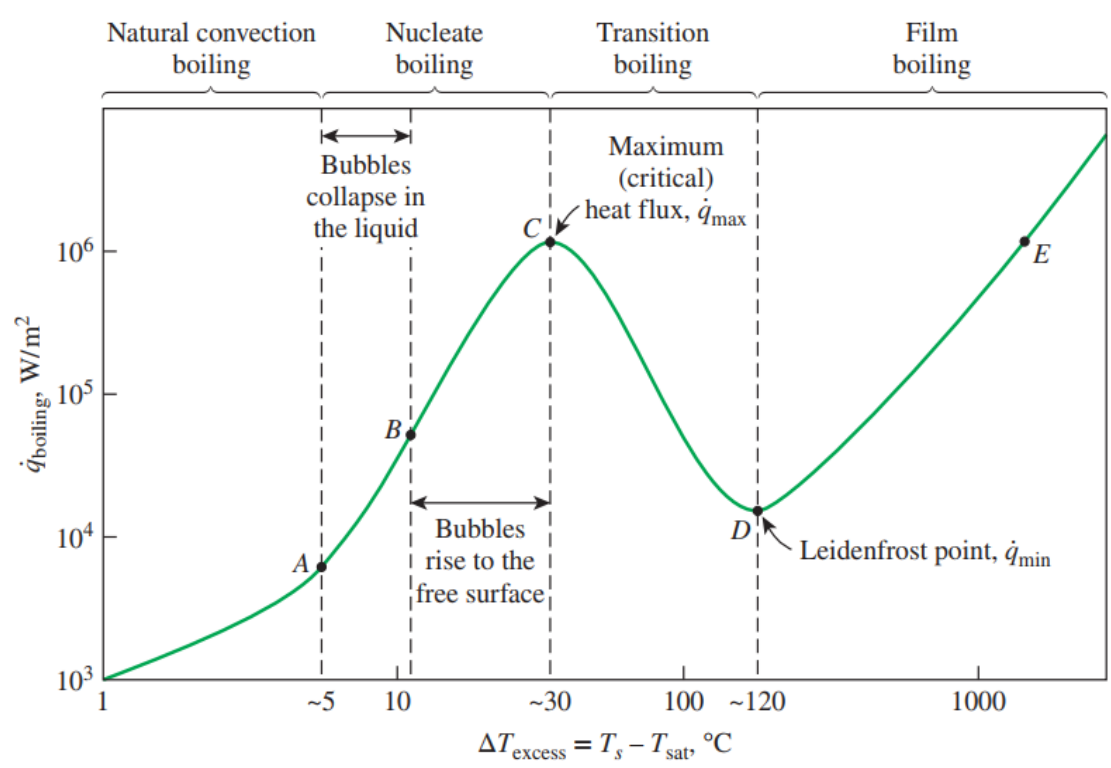

a)

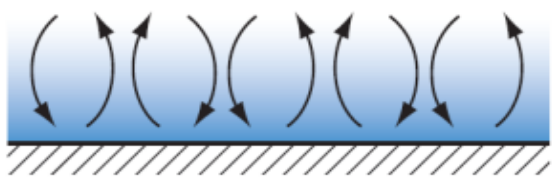

1. Natural convection

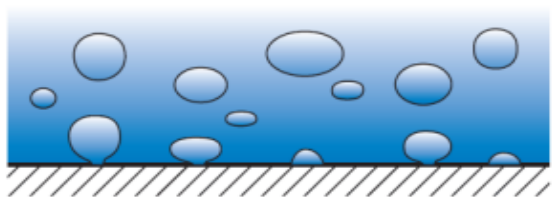

2. Individual bubble regime

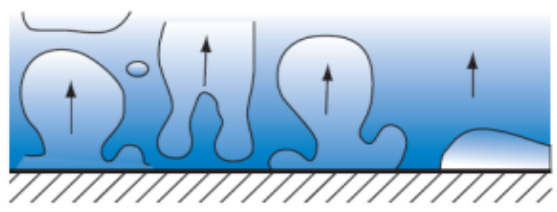

4. Transition film boiling

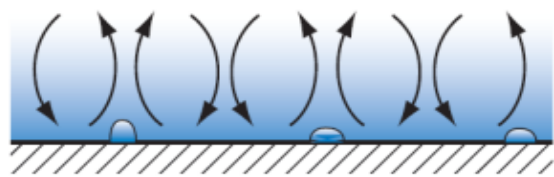

Onset of boiling

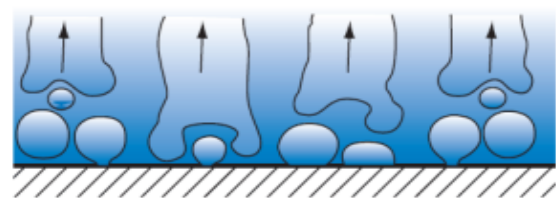

3. Regime of slugs and bubbles

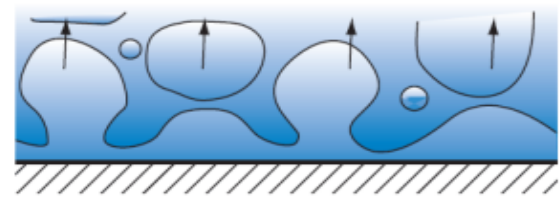

5. Stable film boiling

b)

Figure 3: The a) pool boiling curve with b) schematic representation of each boiling regime $[5,6]$

\section{MORE ABOUT NANOFLUIDS}

\subsection{Why Nanofluids in Boiling Heat Transfer?}

In recent times the experimental research has shown that nanofluids have more thermal conductivity than the base fluids. Nanofluids have many advantages of over the traditional solid-liquid suspensions. Some of them are as follows:

1. There are a greater specific surface area and greater stability of the colloidal suspension.

2. It lowered the pumping power to accomplish same heat transfer amplification compared to the base fluid.

3. It reduced particle obstruction in comparison with convention slurries, thus helping system reduction.

4. By changing particle concentrations to suit various applications, regulating properties, including thermal conductivity and surface wettability [7].

5. The properties of the fluid will differ by adjusting the concentration of the nanoparticles in order to make it suitable for various applications.

6. Nanofluids have minimum pressure drop as the particles are nanometre in size.

7. Nanofluids are also fit for fast heating and cooling systems. 
8. By using nanofluids heat exchanger systems can be made smaller and lighter that will result in cost as well as energy savings.

It is notably observed that the heat transfer coefficient and critical heat flux can be increased by using nanofluids in the boiling heat transfer. This improved heat transfer coefficient and critical heat flux can be implemented in the design of heat exchangers and heat storage systems. For these reasons, nanofluids are important for boiling heat transfer research.

\subsection{How Does Nanofluid Work?}

Heat transfer relies on the stroll of the molecules within the substance. Temperature can be a range in which the movement energy of substance molecules is expressed in order to increase the temperature, energy from outside must be given to a substance. By altering the density and specific heat, nanofluid enhances the heat transfer characteristics of water. Despite the fact that water is generally utilized as a heat transfer medium, it is certainly not an ideal base liquid. The nanofluid heat transfer is more in contrast to the base fluid. As a result of this enhance in heat transfer nanofluid allows the heat to be transferred to the target faster and more efficiently. Nanofluid provides higher efficiency with lower energy [8].

\section{PREPARATIONS OF NANOFLUID}

The nanofluid generation to alter the rate of heat transfer of traditional fluids is the most significant step in the use of Nano phase particles. As a liquid-solid mixture, the nanofluid is not only stated. Nanofluids consist primarily of carbides, oxides, metals and carbon nanotubes which, with the addition of stabilizing agents, can simply be circulated into heat transfer fluids, like as hydrocarbons, water and ethylene glycol. Several processes, namely gas condensation, mechanical attribution, or chemical precipitation, may also create nanoparticles. Under cleaner conditions, these nanoparticles can also be produced and their surface can be saved from sudden coatings that can occur during the gas condensation phase [8,9]. The simple procedure of nanofluids preparation is shown in figure 4, Where nanoparticles are fixed up with base fluids in order to get the nanofluids [10]. Two key methods of preparing nanofluids are available. Single-step method and Two-step method.
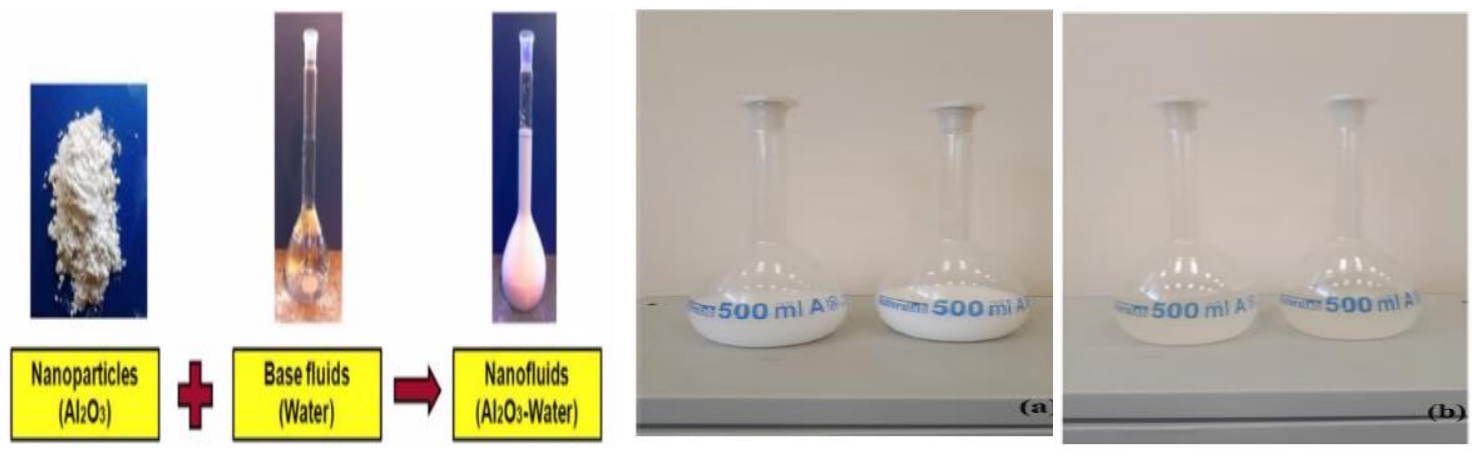

Figure 4: Simple procedure of nanofluids preparation. (a) h-BN nanofluid, (b) $\mathrm{SiO}_{2}$ nanofluid [10]

\subsection{Single-Step Method}

A single-step method has been developed to decrease the synthesis of nanoparticles. Using this process, there are many ways to prepare nanofluids, including direct condensation of evaporation, condensation of chemical vapour and chemical synthesis in one step [9]. The single-step process, also known as the direct evaporation condensation method, consists of following main stages.

1. The base fluid for example water or ethylene glycol is circulated in the inner part of a cylinder so that a thin film of the fluid is regularly expelled out of the upper of the chamber.

2. Small pieces of metal evaporate using heat to form nanoparticles.

3. Finally, the fluid is allowed to cool downwards to avoid any unwanted evaporation.

\subsection{Two-Step Method}

Most commonly, this process is used to make nanofluids. A two-step process where nanoparticles or nanotubes are formed as a dry powder chemically or physically for the first time. In the second level, the resultant nanoparticles are dispersed in the liquid with the aid of intense magnetic energy movement, ultrasonic movement, high shear mixing, homogenization, and ball milling. As the nano powder synthesis methods have already been measured at the industrial production level, the two-step approach is the most reasonably priced approach for manufacturing nanofluids on a large scale. The two-step method for nanofluids preparation is shown in figure 5 . Due to a higher surface area and surface activity, nanoparticles tend to accumulate. Using surfactants is a vital method to improve the stability of nanoparticles in liquids. Several advanced nanofluid production technologies (including the one-step process) have been developed due to the complexity of preparing stable nanofluids using the two-step method [8]. 


\section{NANOFLUIDS ENHANCEMENT ON BOILING}

Boiling has an important character in several engineering application and technological regions, for example electricity generation, nuclear reactor cooling, cooling of electronic components, etc. There are a many research and review articles regarding nanofluids; few on their expected advantages on heat transfer applications and furthermore few on their heat conductivity improvement. The usage of nanofluids for boiling enhancement is a promising zone that is as of now being explored by various researchers for pool boiling and as of late for flow boiling applications. Figure 6 shows the quick advancement of yearly research publications on nanofluids boiling heat transfer. In latest years, a sharp increase in nanofluid boiling studies have found because of the higher thermal conductivity of nanofluids. In this review article, all prevalent pool boiling and flow boiling articles using nanofluids to date have been consolidated. A summary related to pool boiling and flow boiling of nanofluid studies has been provided in the later section. It is to be hoped that this article will give a brief and reasonable record of the benefits and restrictions of nanofluids in regard to their boiling performance and application.

In Figure 7, the first number means number of articles reviewed of a nanoparticle or a series of nanoparticles and the following percentage means the corresponding percentage of that nanoparticles within the total percentage.

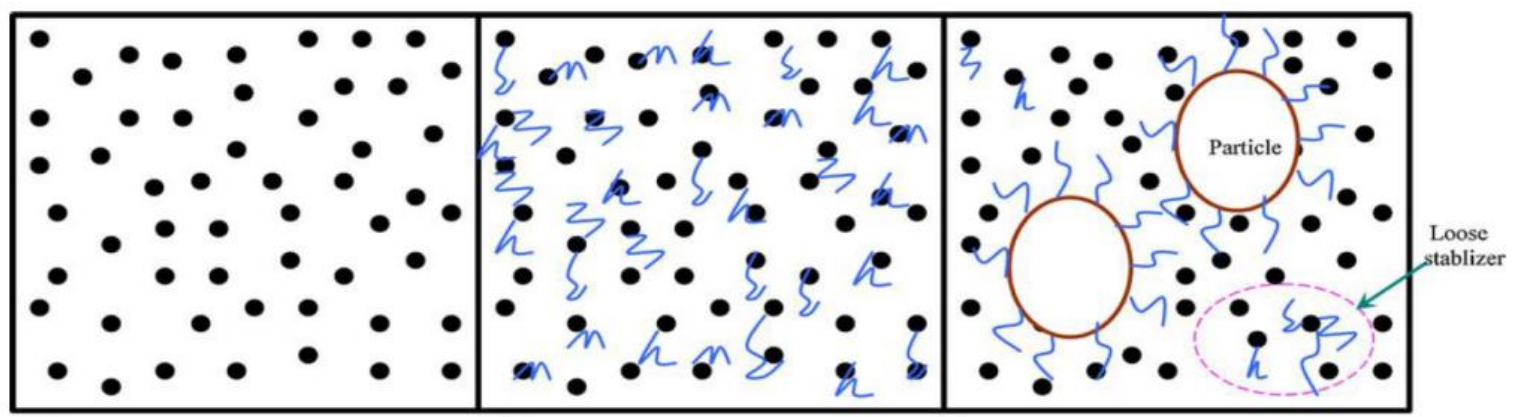

(a) Pure liquid

(b) Pure liquid + stabilizers

(c) Nanofluids with loose stabilizers

Figure 5: Two-step method for nanofluids formulation [7]

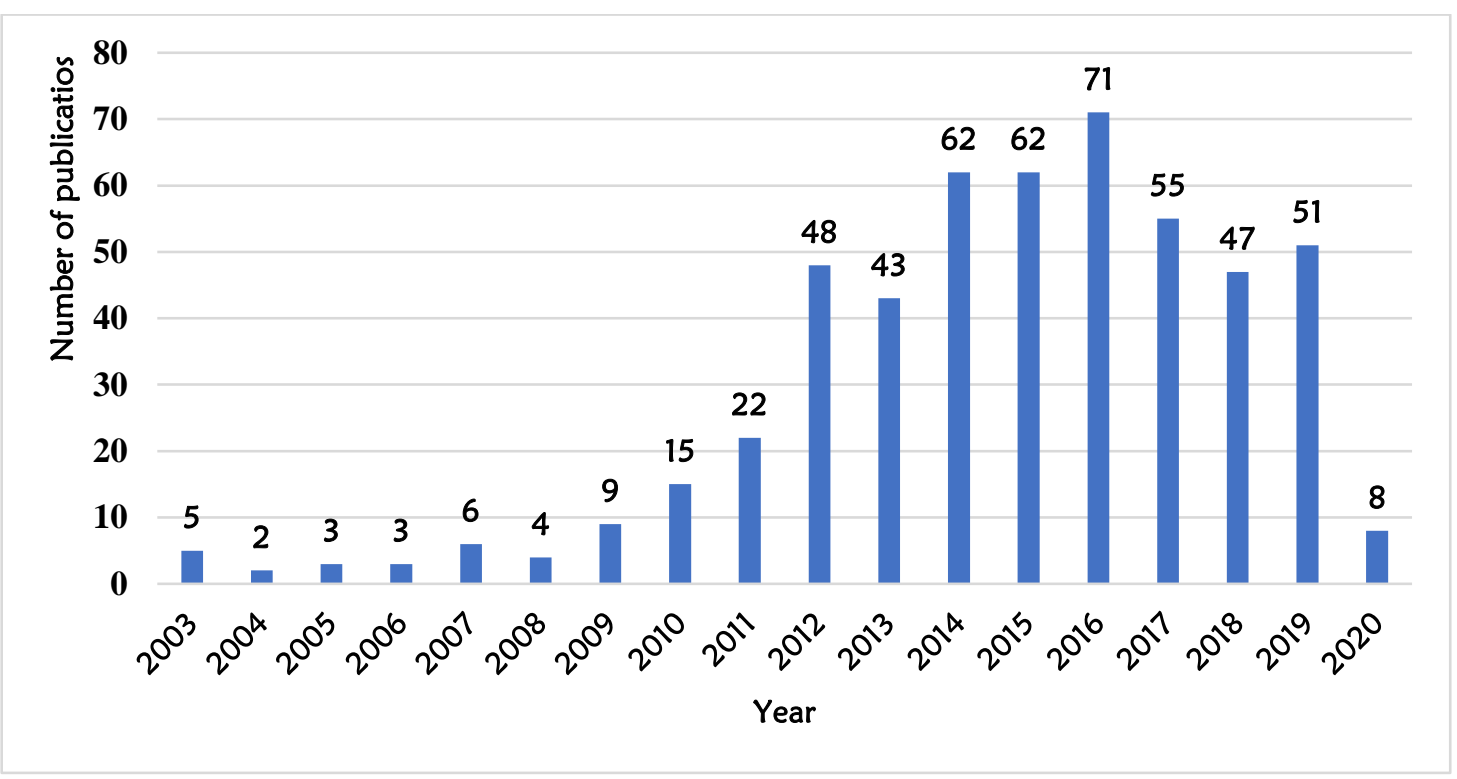

Figure 6: Annual publications on boiling heat transfer nanofluids since 2003 

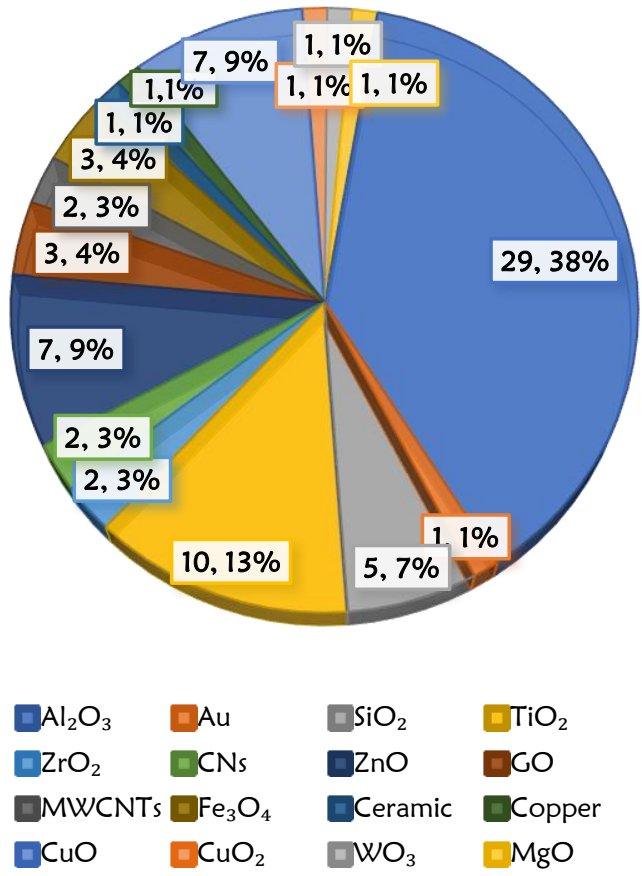

(a)

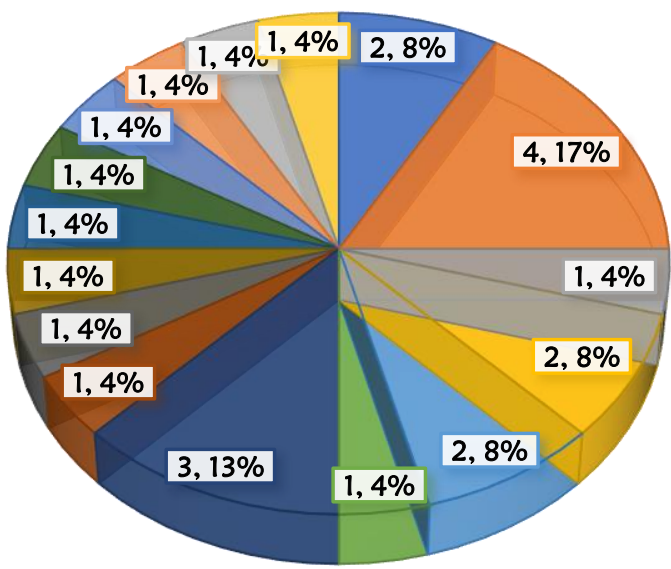

$\mathrm{Al}_{2} \mathrm{O}_{3}, \mathrm{ZrO}_{2}$ and $\mathrm{SiO}_{2}$
$\mathrm{Al}_{2} \mathrm{O}_{3}$ and $\mathrm{Bi}_{2} \mathrm{O}_{3}$
$\mathrm{H}_{2} \mathrm{O} / \mathrm{LiBr}+\mathrm{Al}_{2} \mathrm{O}_{3}$
$\mathrm{Al}_{2} \mathrm{O}_{3}, \mathrm{ZnO}$, and Diamond
$\mathrm{Al}_{2} \mathrm{O}_{3}$ and $\mathrm{Cu}$
$\mathrm{MWCNTs} \mathrm{CuO}$ and $\mathrm{Al}_{2} \mathrm{O}_{3}$
$\mathrm{Al}_{2} \mathrm{O}_{3}$ and $\mathrm{SiO}_{2}$

(b)

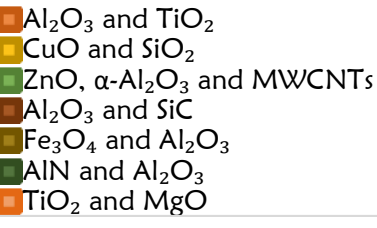

Figure 7: Number of articles reviewed with their corresponding percentage (a) nanoparticles (b) that use a series of nanoparticles or binary nanoparticles

\subsection{Literature Review on Pool Boiling of Nanofluids}

Since 2003, many research papers have been published on nanofluid pool boiling, that are listed in Table 1 to Table 4. In this literature review, the impacts of nanofluids on the most significant parameters, like HTC and $\mathrm{CHF}$, in pool boiling is studied. The recent enhancement pool boiling heat transfer with nanofluids are discussed below.

Ciftci et al. [10] experimentally and numerically scrutinized the heat transfer enhancement in pool boiling and condensation by changing the hydrophilicity or hydrophobicity properties of the working fluid, i.e. by using nanofluid solution. In order to determine the influence of nanoparticle concentration on heat transfer properties, two separate nanofluid solutions ( $\mathrm{h}-\mathrm{BN} / \mathrm{DCM}$ and $\mathrm{SiO}_{2} / \mathrm{DCM}$ ) were arranged and tested for three distinct volumetric concentrations as well as different heat flux conditions. The boiling curves for DCM, h-BN/DCM and $\mathrm{SiO}_{2} / \mathrm{DCM}$ nanofluids under saturation and after saturation conditions at various concentration is shown in figure 8 . The enhancement rate of HTC for saturation boiling, boiling after saturation, and condensation methods was found to be $27.59 \%, 14.44 \%$, and $15 \%$ respectively for the experimental outcomes of $\mathrm{h}-\mathrm{BN} / \mathrm{DCM}$ nanofluid and for $\mathrm{SiO}_{2} / \mathrm{DCM}$ nanofluid it was $20.69 \%, 16.67 \%$, and $21.86 \%$, respectively.

A theoretical analysis was carried out by J. Ham et al. [11] on pool boiling features of $\mathrm{Al}_{2} \mathrm{O}_{3}$ nanofluids based on volume concentration and nanoparticle size by using the HFP (heat flux partitioning) model with variations in the contact angle. Their result showed that the CHF base of nanofluids is higher than that of the liquid. The most critical heat flux was found to be $1,515 \mathrm{~kW} / \mathrm{m}^{2}$ under a volume density of $0.05 \mathrm{vol} . \%$ and was gradually reduced with the density of nanofluids and the size of $\mathrm{L}_{2}$ and $\mathrm{L}_{3}$-nanoparticles was $50 \mathrm{~nm}$ and decreased gradually.

Donga et al. [12] investigated an experiment on boiling heat transfer characteristics of $\mathrm{Al}_{2} \mathrm{O}_{3}-$ water nanofluid in swirl micro channels subjected to an acceleration force. They applied three test sections with dissimilar geometric parameters. The concentration ( $v o l$.) of $\mathrm{Al}_{2} \mathrm{O}_{3}$ nanoparticles (average diameter of $13 \mathrm{~nm}$ ) was changed from $0.07 \%$ to $0.1 \%$. The mass flow rate and vapour qualities were between $3-6 \mathrm{~kg} / \mathrm{h}$ and $0.4-1.0 \%$, respectively. Their investigational outcomes showed that the direction and width of the acceleration had an important influence on the $\mathrm{BHT}$ and that $\mathrm{HTC}$ increased with the increasing of mass flow rate and volume concentration increased and reduced with the direction ratio.

Khliyeva et al. [13] experimentally studied the impact of nanoparticle added substances to the refrigerant R141b on the pool boiling process. They observed that TiO2 nanoparticles additives to the R141b / Span-80 solution contributed to a 2-8-fold reduction in the amount of nucleation sites. They also observed that the increase in heat flux contributes to a rise in the disparity between the nucleation site density magnitudes in R141b and R141b/Span80 boiling. At a heat flux of $7.5 \mathrm{~kW} / \mathrm{m}^{2}$, compared to boiling on the stainless-steel surface, the amount of nucleation 
sites on the Teflon surface was 2 times lesser. They also found that the form of surfaces did not affect the number of nucleation sites and the frequency of vapor bubble take-off in nanofluid boiling in the whole explored the scope of heat fluxes and the frequency of vapor bubble departure in R141b boiling and R141b/Span-80 solution on the Teflon surface 1.5-2 times lower compared to boiling on the surface of stainless steel.

An experimental study was directed by Sarafraz et al. [14] on the thermal behaviour of the $\mathrm{ZnO}$ nanoparticles dispersed in water-ethylene glycol (water/EG) as the base fluid under the pool boiling condition. They investigated the effects of various operational factors like as heat flux and mass concentration on HTC and thermal fouling resistance provided by heat $\mathrm{ZnO}$ nanofluid. Their findings showed that the HTC for $\mathrm{ZnO} /$ water/EC nanofluids increased with the rise in heat flux and mass concentration at a concentration of $0.5 \%$ by weight. With increasing in the nanoparticle mass concentration, the CHF point was increased because of the increase in the nanoparticle's deposition layer.

Kamel et al. [15] experimentally investigated the performance of pool boiling heat transfer by using tungsten oxide $\mathrm{WO}_{3}$ nanomaterial-based deionized water nanofluids. They made $\mathrm{WO}_{3}$-based water nanofluids by using twostep process. The most important steps they observed were to achieve a stable suspension during the creation of nanofluids. Figure 9 shows the different boiling phenomena of their experiment at different volume fractions. Their experimental findings showed that at concentrations of $0.005 \%$ vol., the PBHTC ratio increased by around $6.7 \%$ and 0.01 vol.\% in the high heat flux area. While there was a decrease in this ratio by about $15 \%$ at a volume concentration of $0.05 \%$ vol. in the low heat flux area.

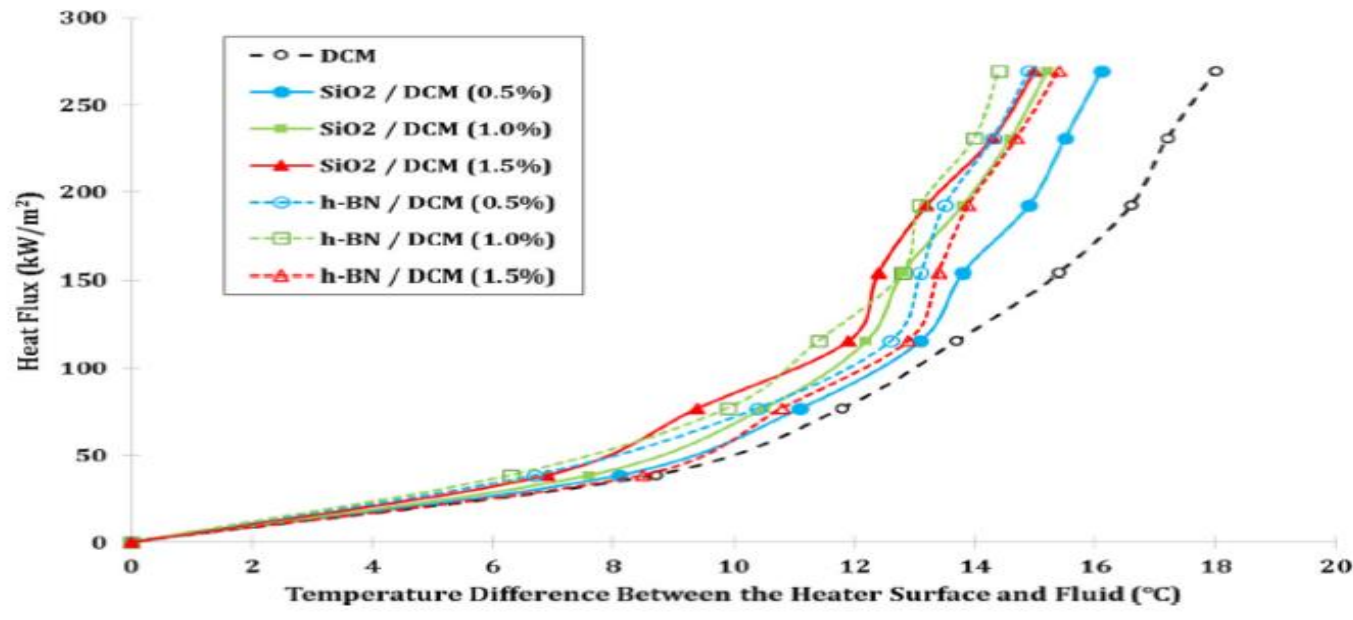

(a)

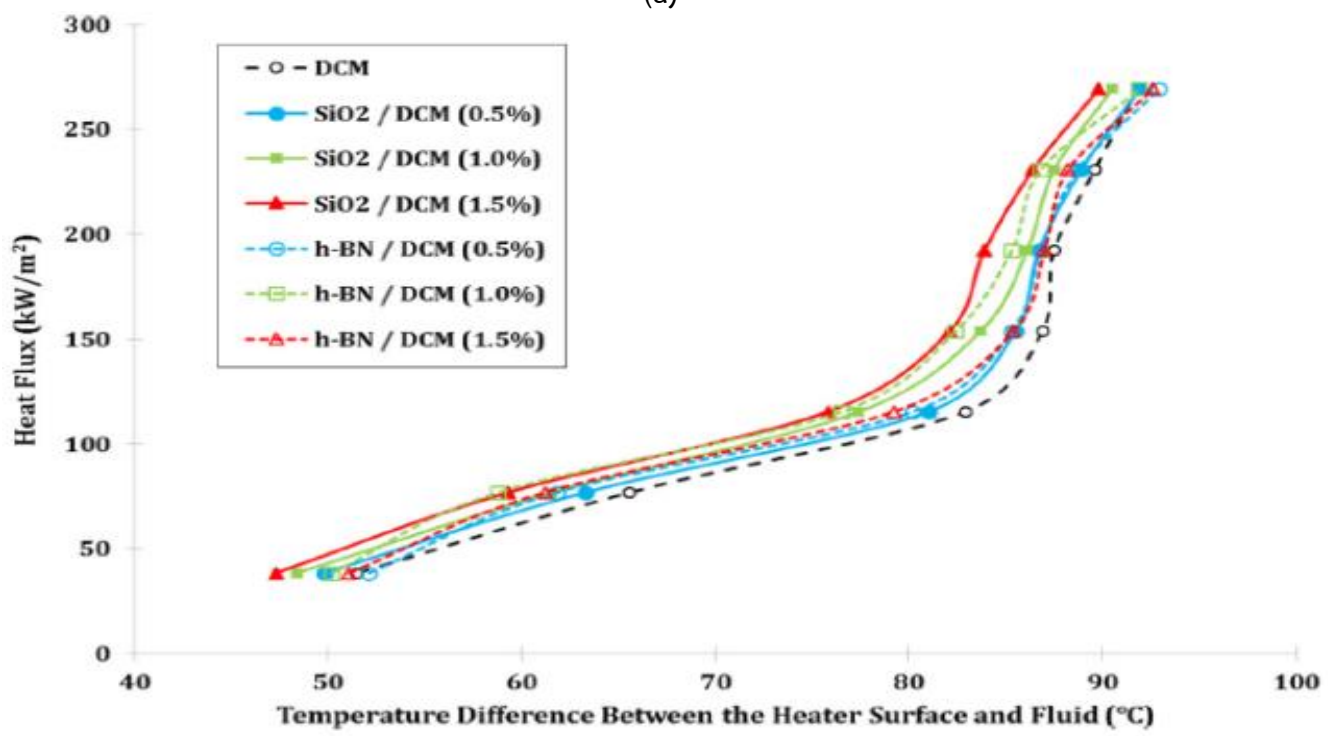

(b)

Figure 8: Boiling curves for $\mathrm{DCM}, \mathrm{h}-\mathrm{BN} / \mathrm{DCM}$ and $\mathrm{SiO}_{2} / \mathrm{DCM}$ nanofluids under (a) saturation (b) after saturation conditions at various concentration [10] 
Yanwei et al. [16] investigated the boiling heat-transfer properties of ethylene glycol (EG) and water $\left(\mathrm{H}_{2} \mathrm{O}\right)$ mixture based $\mathrm{SiO}_{2}$ nanofluid under realistic conditions. They used a 0.6 vol.\% EG aqueous solution as a base liquid due to the perfect frost-proofing performance of $\mathrm{CO}_{2}$ nanofluids based on a mixture of E-glycol (EG) and water $\left(\mathrm{H}_{2} \mathrm{O}\right)$ in realistic situations. Their results showed that the nanoparticle diameter decreased from $120 \mathrm{~nm}$ to $64 \mathrm{~nm}$, increasing the boiling heat-transfer coefficient (HTC). Also, with increasing in the concentration of nanoparticle, initially HTC was found to be increased quickly and then showed a decrease of $0.25-1.00 \%$ in the concentration range. Also, above 0.75 vol.\%. nanoparticle, HTC decreased.

Shoghl et al. [17] conducted an experimental study regarding boiling performance of $\mathrm{ZnO}, \alpha-\mathrm{Al}_{2} \mathrm{O}_{3}$ and MWCNTs/water nanofluids. The $\mathrm{ZnO}$ and $\mathrm{Al}_{2} \mathrm{O}_{3}$ nanoparticles impairing heat transfer when add MWCNTs resulted in improving heat transfer. The essential effect of nanofluid which was attributed to the reference heat transfer coefficient improved by $\mathrm{ZnO}$ and $\mathrm{Al}_{2} \mathrm{O}_{3}$ while decreased by CNTs at the low concentrations (0.01 wt.\%).

Aizzat et al. [18] conducted an experiment to identify the Heat Transfer Coefficient (HTC) in saturated pool boiling of single and hybrid water-based nanofluids. They chose $\mathrm{Al}_{2} \mathrm{O}_{3}$ and $\mathrm{SiO}_{2}$ nanoparticles and mixed into two different single nanofluids and mixed to achieve a ratio of 0:100, 25:75, 50:50, 75:25, and 100:0 \% to 0.001 vol. percent final concentration. On a regular basis, they used these blends to achieve HTC standards through experimental work. They found that at the lowest concentration of $\mathrm{Al}_{2} \mathrm{O}_{3}$ nanofluids $(0.00025$ vol.\%), HTC improved significantly but decreased for $\mathrm{CO}_{2}$ nanofluids. Distinctly, as with hybrid nanofluids, HTCs were dramatically improved in the early stages but gradually decreased over time, especially in the case of higher proportions of $\mathrm{SiO}_{2}$ nanofluids.

Girish Sapre et al. [19] conducted an experiment on Pool Boiling Heat Transfer using Titanium Oxide $\left(\mathrm{TiO}_{2}\right)$ and Magnesium Oxide (MgO) nanofluids. Their experimental setup consisted with a Borosil transparent glass vessel having size $130 \mathrm{~mm}$ diameter and $205 \mathrm{~mm}$ height. Due to increased thermal conductivity of nanofluid and other reasons such as presence of Brownian motion and diffusion of nanoparticles in distilled water the Critical Heat $\mathrm{Flux}_{\text {of }} \mathrm{TiO}_{2}$ and $\mathrm{MgO}$ nanofluid are superior to the distilled water and keep on increasing with the volume fraction, both fluids show significant increment in the CHF. Their result also showed that $\mathrm{CHF}$ improves in the range of $10.51 \%$ to $52.42 \%$ in case of $\mathrm{TiO}_{2}$ and $23 \%$ to $60.88 \%$ in case of $\mathrm{MgO}$ nanofluid with increasing in volume fraction.

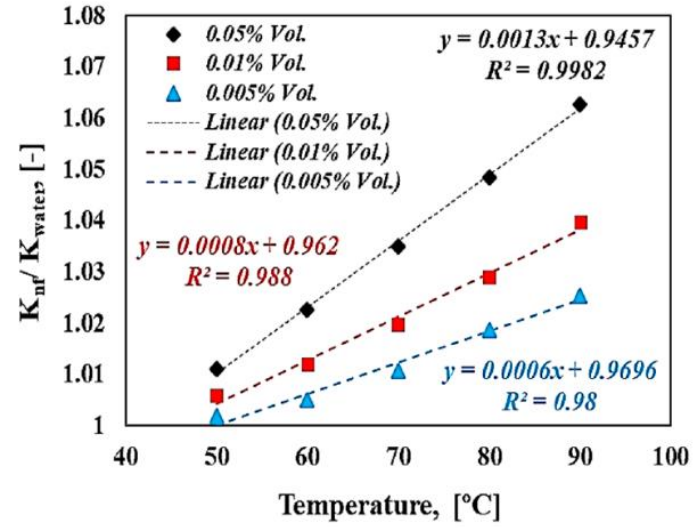

(a)

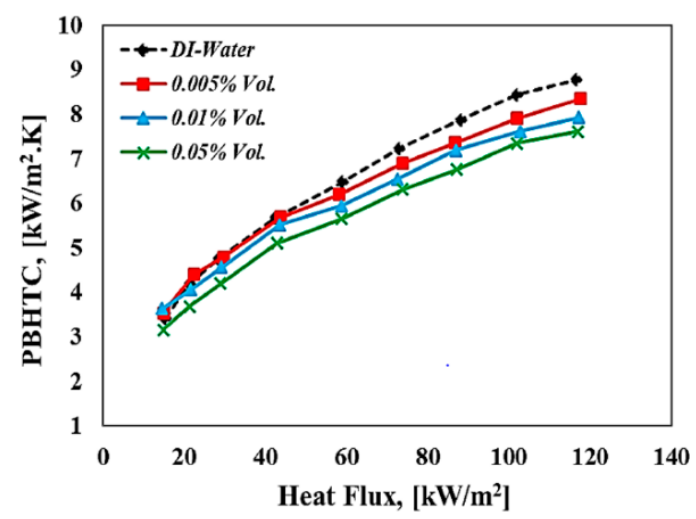

(c)

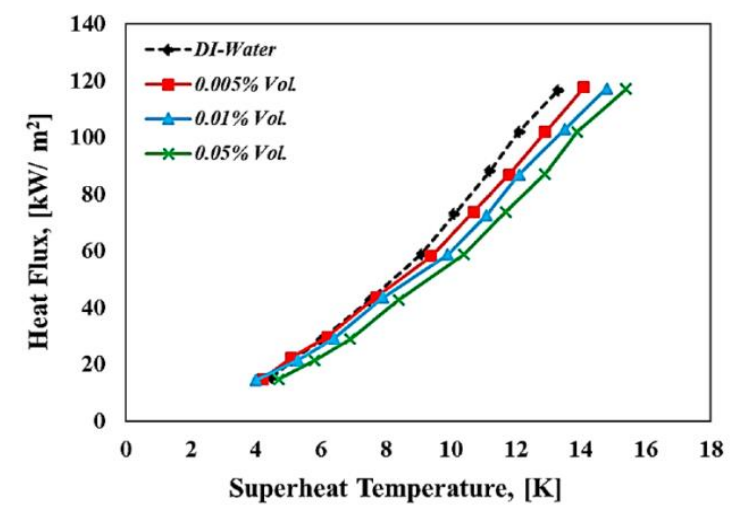

(b)

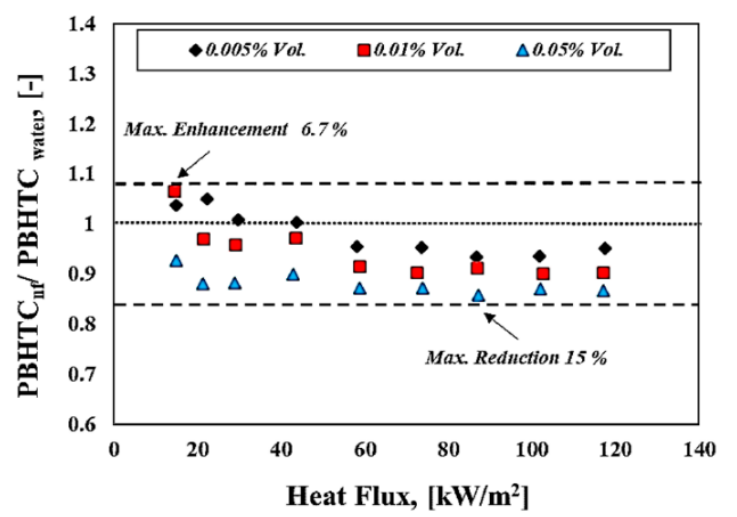

(d)

Figure 9: Different boiling phenomena for $\mathrm{WO}_{3}$-based water nanofluids at different volume fractions [15] 


\subsection{Literature Review on Flow Boiling Heat Transfer of Nanofluids}

A boiling heat transfer process in which an external means, as well as natural convection and bubble-induced mixing artificially causes the fluid motion is known as flow boiling. It can be used in a range of industrial applications, for example air conditioning, cooling of nuclear reactors, components of power plants (boilers), refrigeration, petroleum, and high-tech electronic cooling of components. In order to improve the efficacy of such applications in terms of heat removal or cooling systems, it is important to boost the heat transfer method of flow boiling to find a substantial decrement from the consumption of energy. The use of solid nanoscale particles with traditional cooling fluids is one of the most successful methods to enhance the flow boiling heat transfer. This solution will give new and imaginable energizing results compared to host fluids to increase thermal exchange efficiency. For certain fluids, nanofluids build a fresh fluid category and a promising next-generation. Since 2003 a lot of research paper have been published on nanofluids flow boiling, that are listed in Table 5 to Table 8. In these studies, similar to pool boiling, the influence of nanofluids on the significant factors, like as HTC and CHF, in flow boiling have been studied. The recent flow boiling heat transfer enhancement on nanofluids are discussed below.

Sudheer et al. [20] investigated an experimental studies of heat transfer and flow regimes during flow boiling of water and alumina nanofluids at different heat and mass fluxes. They investigated the flow boiling heat transfer in a vertical pipe of internal diameter $7.5 \mathrm{~mm}$ with pure water and $\mathrm{Al}_{2} \mathrm{O}_{3} /$ water nanofluid as working fluids. For their study, they considered the particle concentrations of $0.001 \%, 0.005 \%$ and $0.01 \%$. From the results, it was seen that flow boiling HTC was increased with mass flux for both water and nanofluids. It was also found that the HTC increased with particle concentration due to the altered characteristics of the heater surface and changes in the process of bubble formation. The average rise in heat transfer coefficient, in comparison with the base fluid, for the nanoparticle concentrations of $0.001 \%, 0.005 \%$ and $0.01 \%$ at a mass flux of $905.42 \mathrm{~kg} / \mathrm{s}-\mathrm{m}^{2}$ was found to be $12.11 \%$, $21.75 \%$ and $27.97 \%$, respectively. The flow boiling HTC was seen to be more for the nanofluids compared to water.

Wang et al. [21] investigated experimentally the study on $\mathrm{Al}_{2} \mathrm{O}_{3} / \mathrm{H}_{2} \mathrm{O}$ nanofluid flow boiling heat transfer under different pressures. By ultrasonic oscillation, the $\mathrm{Al}_{2} \mathrm{O}_{3} / \mathrm{H}_{2} \mathrm{O}$ nanofluid was prepared. The nanoparticle concentration was 0.1 and 0.5 vol. percent with diameter $20 \mathrm{~nm}$. Their results indicated that the heat transfer rate of $\mathrm{Al}_{2} \mathrm{O}_{3} / \mathrm{H}_{2} \mathrm{O}$ nanofluid was increased in flow boiling by roughly $86 \%$ as compared to pure water. In their range of work, the rise in the average number of Nusselt nanofluids compared to deionized water was 35 percent.

Om Shankar et al. [22] studied an experiment on the flow boiling HTC by using ZnO-water nanofluids. Their $780 \mathrm{~mm}$ long annular test section was consisted with an electrically heated rod and a $21.8 \mathrm{~mm}$ internal diameter outer borosilicate glass tube. The heater was made with hollow stainless-steel rods of $12.7 \mathrm{~mm}$ diameter welded at both ends to solid copper rods. By using an ultrasonic vibration mixer, they prepared $\mathrm{ZnO}$-water nanofluids with volume concentrations of $\mathrm{ZnO}$ particles ranging from 0.0001 to $0.1 \%$. They found that, at a higher concentration of nanoparticles $(0.1 \%)$, the HTC increased by $126 \%$ than the base fluid and increased surface roughness of the heater rod by $1367 \%$, because of the deposition of $\mathrm{ZnO} /$ water nanofluid. Figure 10 shows the effect nanoparticle concentration on heat transfer coefficient at various heat flux.
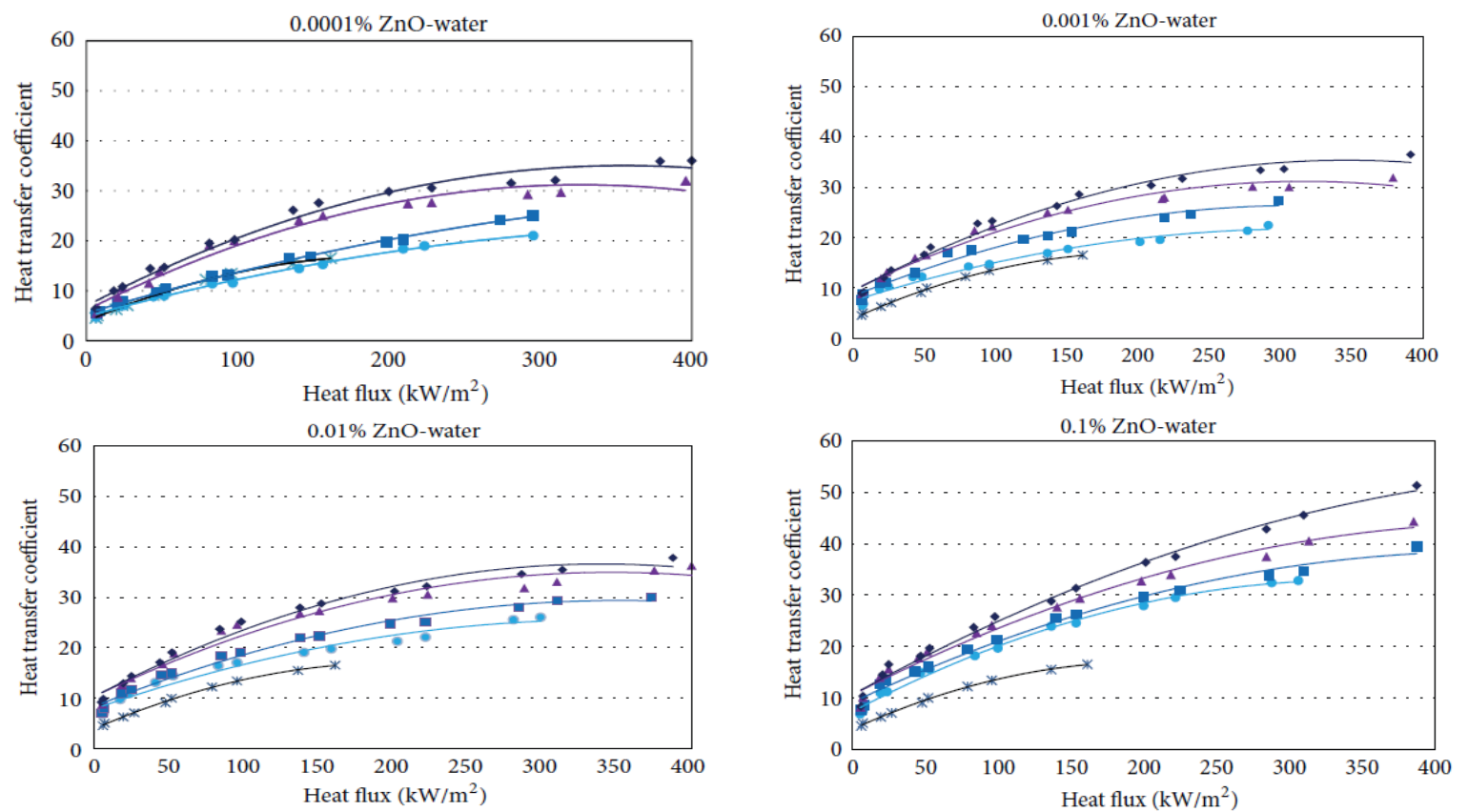

Figure 10: Variation of heat transfer coefficient, $h\left(\mathrm{~kW} / \mathrm{m}^{2} \mathrm{~K}\right)$, of $\mathrm{ZnO}$-water nanofluid with heat flux at different $\mathrm{ZnO}$ nanoparticle volume fraction and $400 \mathrm{~kg} / \mathrm{m}^{2} \mathrm{~s}$ mass flowrate [22] 
Sarafraz et al. [23] conducted an experiment on flow boiling heat transfer coefficients of $\mathrm{DI}-\mathrm{H}_{2} \mathrm{O}$ and $\mathrm{CuO}-\mathrm{H}_{2} \mathrm{O}$ based nanofluids at various working environments. They found that the flow boiling HTC enhanced for DI-water and $\mathrm{CuO}$-water nanofluid in forced convective and nucleate boiling areas by enhancing the applied heat flux. The HTC also increased significantly in both regions by rising the flow rate of fluids. Their findings also revealed that the inlet temperature of fluids played an important character in HTC in nucleate boiling area.

Sarafraz et al. [24] performed an experimental investigation on the flow boiling heat transfer characteristics of $\mathrm{MgO} /$ therminol 66 nanofluid as a potential coolant on a copper-made disc. They prepared nanofluids with the help of two step method at $w t . \%=0.1$, and $w t . \%=0.3$. Results of their experiment showed that the existence of $\mathrm{MgO} /$ therminol 66 growths the flow boiling HTC as compared to the conventional base fluid. However, the coefficient of heat transfer of the nanoparticles decreased with increasing nanoparticle concentration. The HTC was also found to decrease with operating time because of the existence of nanoparticles on the boiling surface, resulting in thermal resistance on the surface being formed. The highest rise in the coefficient of heat transfer was $23.7 \%$ at wt.\% of 0.1 . For wt.\% of 0.2 and 0.3 , the greatest enhancement was found $16.2 \%$ and $13.3 \%$ respectively. Figure 12 shows the several boiling phenomena of their experiment.
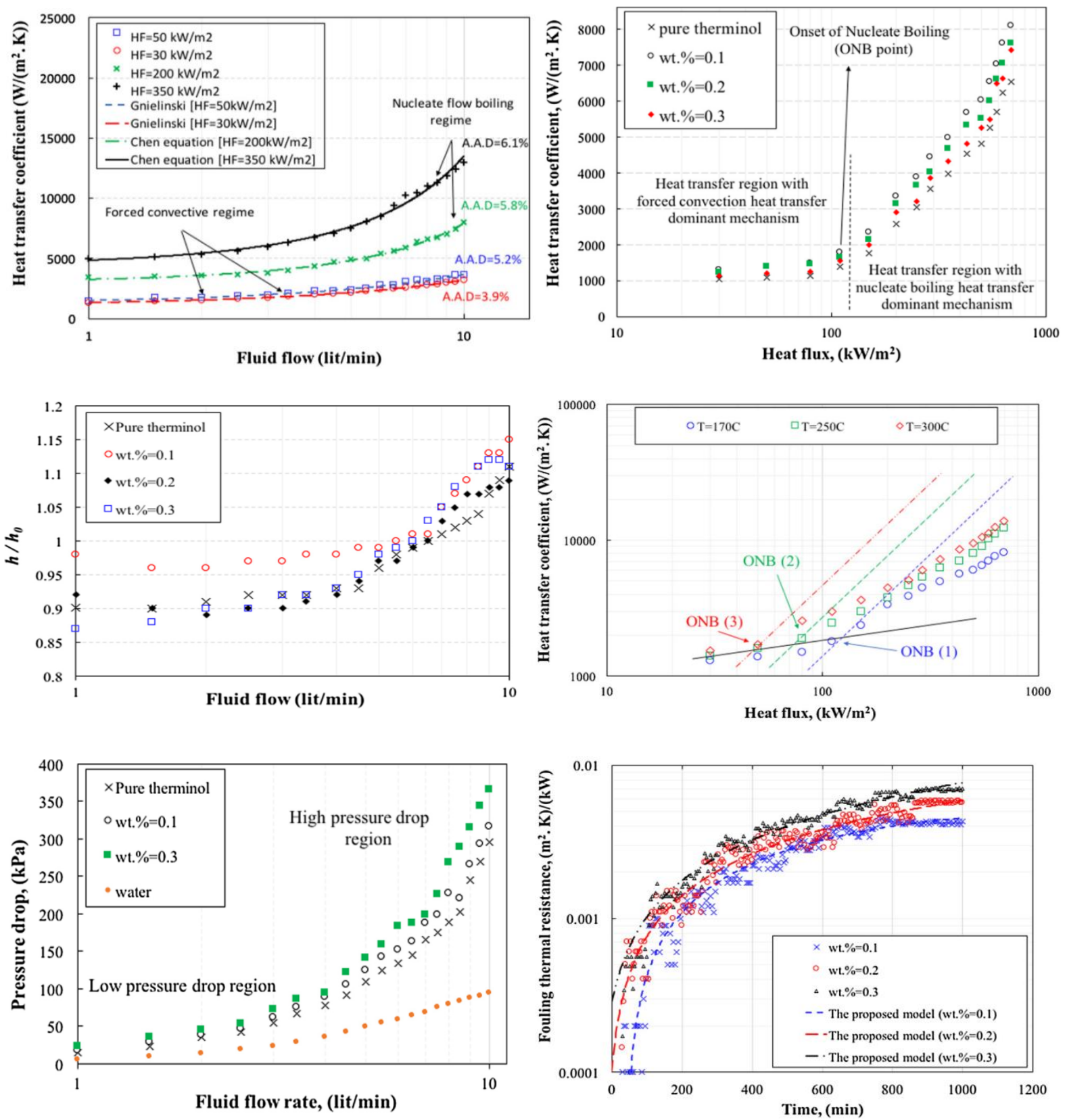

Figure 11: Some of the experimental findings [24] 
Nakhjavani et al. [25] conducted flow boiling heat transfer characteristics of titanium oxide/water nanofluid $\left(\mathrm{TiO}_{2} /\right.$ water) in an annular heat exchanger. They had seen that increasing the volume flow and the heat flux applied would increase the HTC while increasing the nanofluid weight concentration, initially improving the HTC so that the maximum increase in the HTC was $35.7 \%$ at wt. \% of 0.15 and $\operatorname{Re}=13500$ as shown in figure 12 , but over time, the nanofluid HTC decreased. Due to the rise of the IT from $333 \mathrm{~K}$ to $363 \mathrm{~K}$, the maximum change in HTC was 4.2 percent at wt. percent $=0.15$ and $\operatorname{Re}=13500$. The formation of the bubble was also found to be a strong function of the heat flux applied, so that the rate of bubble formation increased with the increase in the heat flux, which was also the reason behind the improvement in the HTC at larger heat fluxes applied. A persistent fouling layer of nanoparticles (NPs) was also found to be formed on the boiling surface, which induced thermal resistance against the transfer of boiling heat. The production of fouling reduced the HTC of the NF so that after 1000 minutes of the heater operation, the extreme reduction in the HTC was $21.6 \%$.

Wang et al. [26] conducted a mechanism of heat transfer enhancement and decrease of nanofluid flow boiling heat transfer. By considering the pressure, mass flux, and heat flux they experimentally studied the heat transfer characteristics of $\mathrm{SiC} / \mathrm{H}_{2} \mathrm{O}$ and $\mathrm{Graphite} / \mathrm{H}_{2} \mathrm{O}$ nanofluids. They found both enhancement and decrease in boiling heat transfer of nanofluids compared to based fluid. In both cases, they used $0.1 \mathrm{vol} . \%$ the concentration of the nanofluids. The flow BHT capacities of $\mathrm{SiC} / \mathrm{H}_{2} \mathrm{O}$ nanofluid were varied from $-24.7 \%$ to $30.6 \%$ and from $-29.4 \%$ to $13.3 \%$ for Graphite/ $\mathrm{H}_{2} \mathrm{O}$ nanofluid as compared with deionized water several heat and mass flux condition. Figure 13 shows effects of mass flux and wall heat flux on Nusselt number of their experiment.

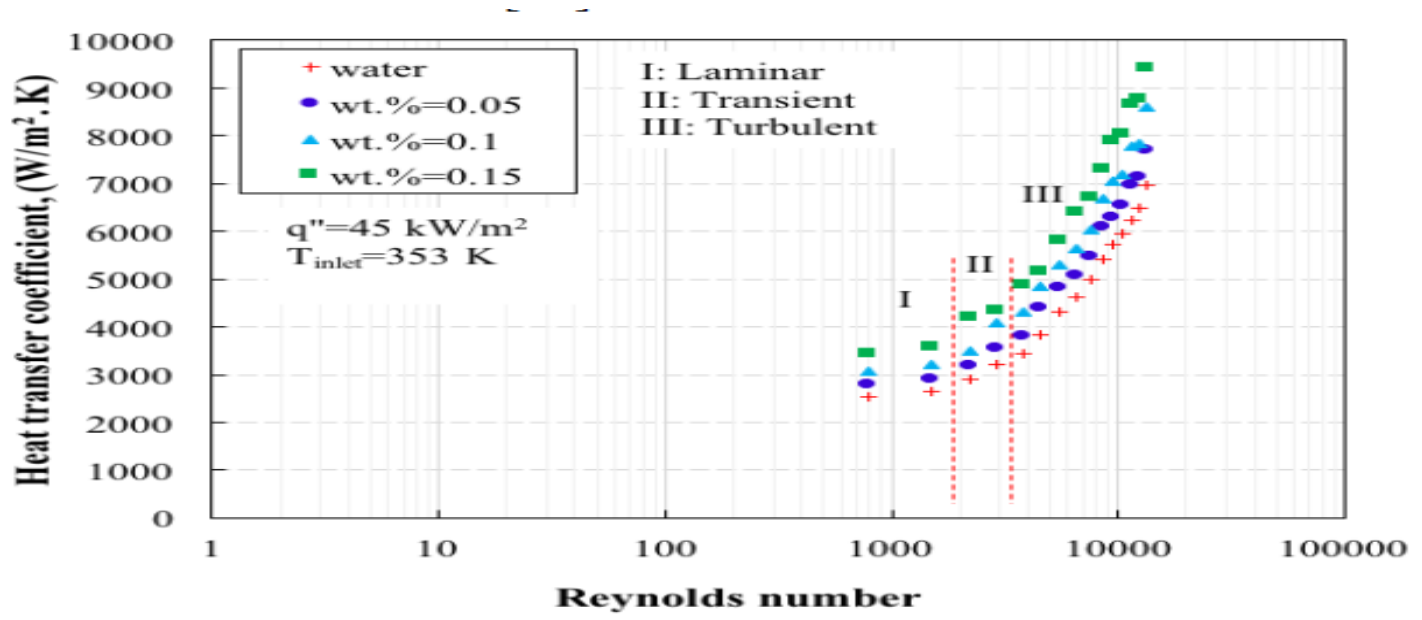

(a)

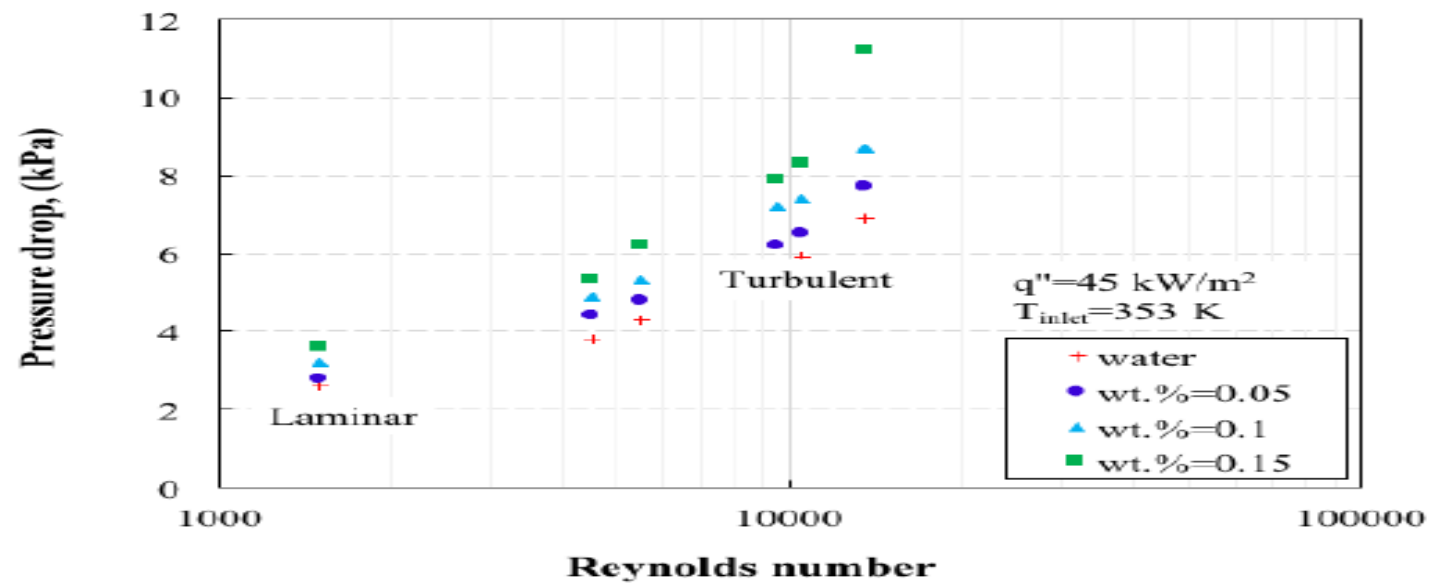

(b)

Figure 12: Effect of the Reynolds number on a) HTC b) Pressure drop [25] 


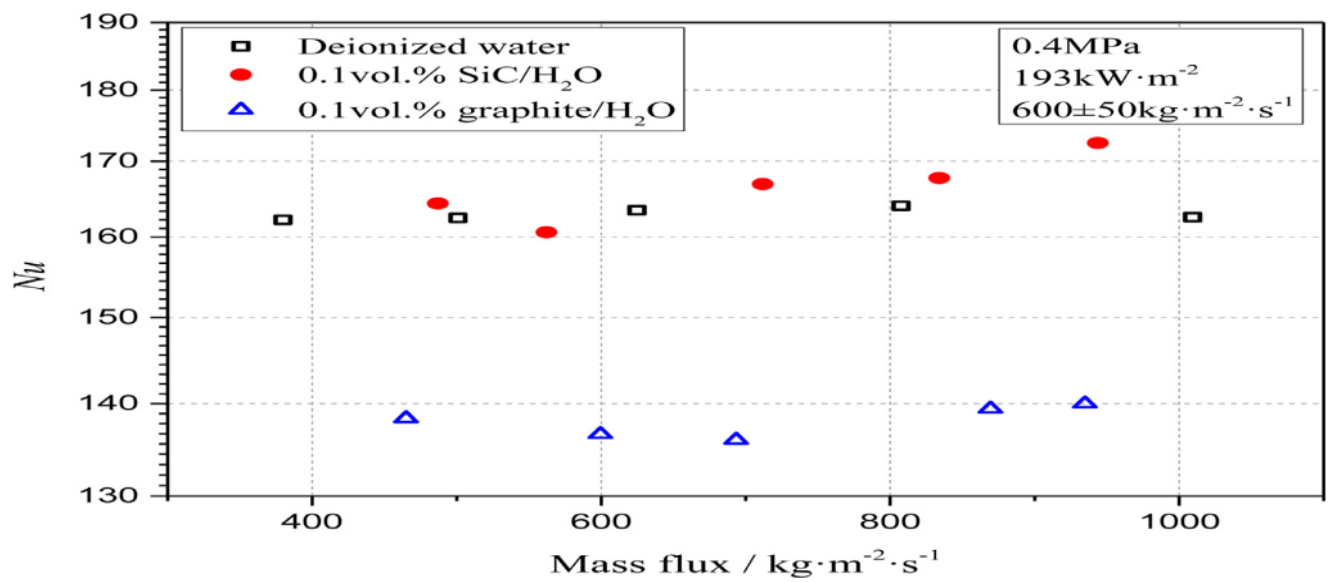

(a)

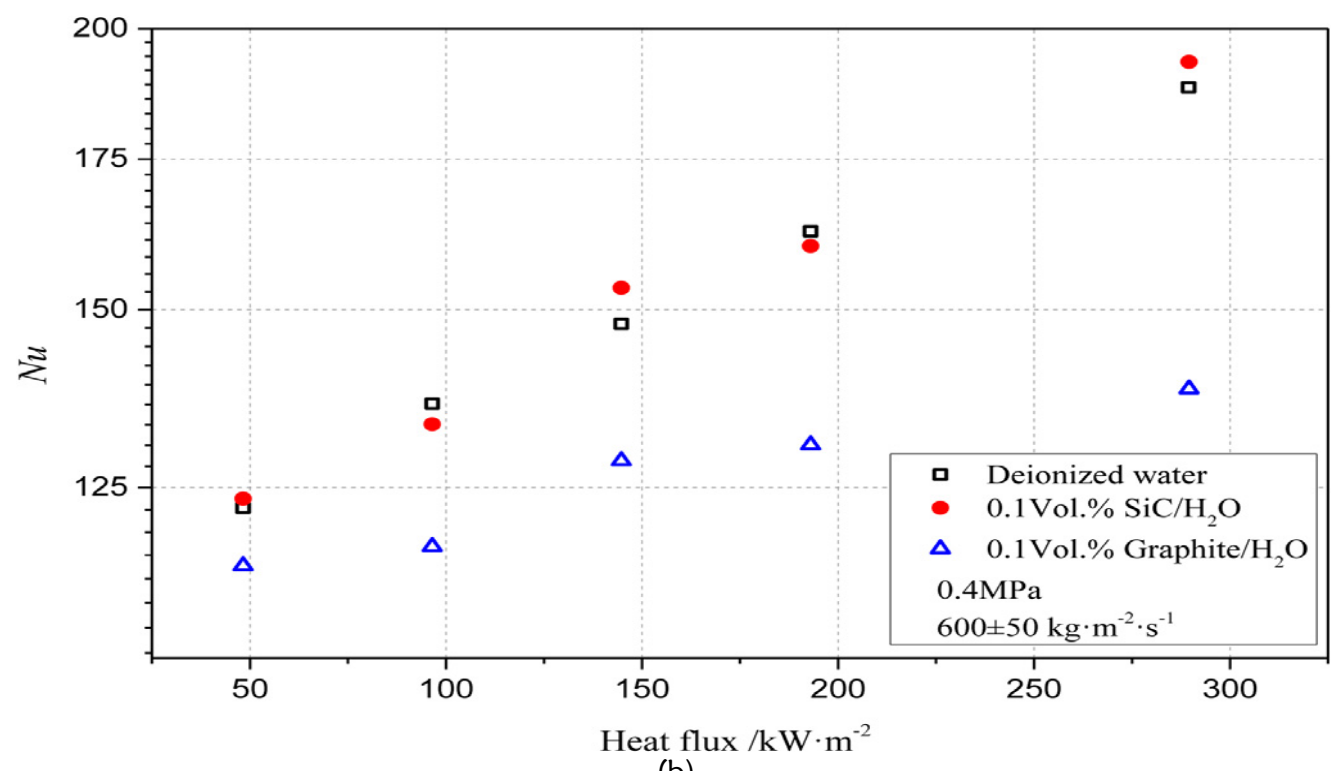

(b)

Figure 13: Effects of a) mass flux and b) wall heat flux on Nusselt number [26]

\section{SUMMARY}

The following tables show the summary of the pool and flow boiling since 2003. Before making the summary table the nanoparticles are classified into four broad classes namely metal, metal oxide, non-metal, and nanoparticle mixture. The available metals that used for the enhancement of boiling heat transfer are $\mathrm{Au}$ and Copper. $\mathrm{H}_{2} \mathrm{O}$ is the only base fluid that used with metal to form the nanofluids. The several metal oxides that used for the enhancement of boiling heat transfer are $\mathrm{Al}_{2} \mathrm{O}_{3}, \mathrm{TiO}_{2}, \mathrm{Bi}_{2} \mathrm{O}_{3}, \mathrm{GO}, \mathrm{CuO}, \mathrm{CuO}_{2}, \mathrm{ZnO}, \mathrm{Fe}_{3} \mathrm{O}_{4}, \mathrm{ZrO}_{2}, \mathrm{CuO}_{2}, \mathrm{WO}_{3}$, and $\mathrm{MgO}$. The several base fluids that are used with the metal oxide to produce nanofluids are $\mathrm{H}_{2} \mathrm{O}, \mathrm{DI} \mathrm{H}_{2} \mathrm{O}$, ethanol, ethylene glycol, pentane, CMC solution, different refrigerants, and polyester oil. Different non-metals like ceramic, $\mathrm{CNs}$, MWCNTs, and non-metallic oxide like $\mathrm{GO}, \mathrm{SiO}_{2}$ are used for the enhancement of boiling heat transfer. Many researchers use binary nanoparticles or a series of individual nanoparticles that are termed as nanoparticles mixture in the summary table.

Table 4 give some brief information regarding the maximum enhancement percentage of pool boiling heat transfer with different nanofluids. Some of the results are related to HTC enhancement percentage, and others are related to CHF enhancement percentage. Many of the research papers didn't mention the amount of enhancement percentage. Few results show that HTC and CHF can also be decreased even by using nanofluids. Based on the availability of the data figures 14 and 15 show the maximum enhancement percentage for different nanoparticles and binary nanoparticles. From the summary Table 1 to Table 4, the maximum increased pool boiling HTC is found as $138 \%$ for $\mathrm{TiO}_{2}$ nanoparticles and the maximum increased critical heat flux is found as $274.2 \%$ for MWCNTs. When two or more nanoparticles in succession or binary nanofluids are used the $\mathrm{CHF}$ increased up to $100 \%$ for $\mathrm{Al}_{2} \mathrm{O}_{3}$ and $\mathrm{TiO}_{2}$. 
Tables 5-6 give some brief information regarding the maximum enhancement percentage of flow boiling heat transfer with different nanofluids. Some of the results are related to the HTC enhancement percentage, and others are related to the CHF enhancement percentage. Many of the research papers didn't mention the amount of enhancement percentage. Few results also show that HTC and CHF can also be decreased even by using nanofluids. This depends on some operating conditions. Based on the availability of the data, figure 16 shows the maximum enhancement percentage for different nanoparticles and binary nanoparticles. From the summary table, the maximum increased heat transfer coefficient is found as $126 \%$ for $\mathrm{ZnO}$ nanoparticles and the maximum increased critical heat flux is found as $100 \%$ for $\mathrm{GO}$ nanoparticles. When two or more nanoparticles in succession or binary nanofluids have used the flow, boiling increased up to $53 \%$ for $\mathrm{Al}_{2} \mathrm{O}_{3}, \mathrm{ZnO}$, and Diamond.

Table 1: Summary of metal nanoparticle with base fluids for pool boiling since 2003.

\begin{tabular}{|c|c|c|c|c|c|}
\hline \multirow{2}{*}{$\begin{array}{c}\text { Enhancement } \\
\text { Medium }\end{array}$} & $\begin{array}{c}\text { Nano- } \\
\text { particles }\end{array}$ & Base & Refuid & $\begin{array}{c}\text { Condition } \\
\text { (Concentration/ } \\
\text { Heater type/ } \\
\text { NPs Size) }\end{array}$ & Observation \\
\hline Metal & $\mathrm{Au}$ & $\mathrm{H}_{2} \mathrm{O}$ & {$[27]$} & $\begin{array}{c}\text { O.001wt\% } \\
\text { Cu plate }\end{array}$ & $\begin{array}{c}\text { BHT enhanced between 11 and 21\%. Rising } \\
\text { particle concentration, BHT increased. }\end{array}$ \\
\hline
\end{tabular}

Table 2: Summary of metal oxide nanoparticle with base fluids for pool boiling since 2003 .

\begin{tabular}{|c|c|c|c|c|c|}
\hline \multirow[b]{2}{*}{$\begin{array}{l}\text { Enhancement } \\
\text { Medium }\end{array}$} & \multicolumn{2}{|c|}{ Nanofluids } & \multirow[b]{2}{*}{ Reference } & \multirow{2}{*}{$\begin{array}{l}\text { Condition } \\
\text { (Concentration/ } \\
\text { Heater type/ } \\
\text { NPs Size) }\end{array}$} & \multirow[b]{2}{*}{ Observation } \\
\hline & $\begin{array}{l}\text { Nano- } \\
\text { particles }\end{array}$ & $\begin{array}{l}\text { Base } \\
\text { fluid }\end{array}$ & & & \\
\hline \multirow{8}{*}{ Metal Oxide } & \multirow{8}{*}{$\mathrm{Al}_{2} \mathrm{O}_{3}$} & $\mathrm{H}_{2} \mathrm{O}$ & [28] & Cu plate & $\begin{array}{l}\text { HTC didn't change as the enhancement } \\
\text { unrelated to increased thermal } \\
\text { conductivity of nanofluids. CHF } \\
\text { increased up to } 200 \% \text {. }\end{array}$ \\
\hline & & $\mathrm{H}_{2} \mathrm{O}$ & [29] & $\begin{array}{l}\text { Stainless steel } \\
\text { plate }\end{array}$ & CHF increased about to $40 \%$. \\
\hline & & $\mathrm{H}_{2} \mathrm{O}$ & [30] & $\begin{array}{l}\text { Stainless steel } \\
\text { plate }\end{array}$ & $\begin{array}{l}\text { BHT decreased. CHF increased up to } \\
50 \% \text {. }\end{array}$ \\
\hline & & $\begin{array}{c}\mathrm{H}_{2} \mathrm{O} \\
\text { and } \\
\text { Ethanol }\end{array}$ & [31] & $\begin{array}{l}\mathrm{Cu} \text { and } \mathrm{CuO}, \\
\text { plates and plates } \\
\text { with glass and } \\
\text { gold coatings. }\end{array}$ & $\begin{array}{l}\text { For bad wetting systems, CHF increased } \\
\text { by up to } 37 \% \text {. The mechanism for CHF } \\
\text { enhancement is the fluid's ability to } \\
\text { increase surface wettability. Only } \\
\text { surface modification caused in CHF } \\
\text { improvement equivalent to nanofluids, } \\
\text { but superheat of the lower wall at } 20^{\circ} \\
\text { C. }\end{array}$ \\
\hline & & $\begin{array}{l}\text { CMC } \\
\text { solu- } \\
\text { tion }\end{array}$ & {$[32]$} & $\begin{array}{l}\text { Stainless steel } \\
\text { cartridge heater }\end{array}$ & $\begin{array}{l}\text { BHT decreased, more noticeable at } \\
\text { higher concentrations of CMC. At } \\
\text { nanoparticle concentration, BHT } \\
\text { increased by up to } 25 \% \text {. }\end{array}$ \\
\hline & & $\begin{array}{l}\mathrm{H}_{2} \mathrm{O}- \\
\mathrm{EC}\end{array}$ & [33] & $0.05-1$ vol. $\%$ & $\begin{array}{l}\text { BHT increased about } 64 \% \text { at } 0.75 \% \\
\text { nanoparticle concentration. }\end{array}$ \\
\hline & & $\mathrm{H}_{2} \mathrm{O}$ & [11] & $\begin{array}{l}0.025 \text { vol. } \%, 50 \\
\mathrm{~nm}\end{array}$ & $\mathrm{CHF}$ of the nanofluid increased. \\
\hline & & $\mathrm{H}_{2} \mathrm{O}$ & [12] & $\begin{array}{l}0.07 \text { to } 0.1 \text { vol. } \% \text {, } \\
13 \mathrm{~nm}\end{array}$ & $\begin{array}{l}\text { HTC increased with increasing the mass } \\
\text { flow rate and the volume } \\
\text { concentration and decreased with the } \\
\text { aspect ratio. }\end{array}$ \\
\hline
\end{tabular}




\begin{tabular}{|c|c|c|c|c|}
\hline$\alpha-\mathrm{Al}_{2} \mathrm{O}_{3}$ & $\mathrm{H}_{2} \mathrm{O}$ & [34] & $0.001-0.1$ vol. $\%$ & $\begin{array}{l}\text { For smooth surface, BHT increased and } \\
\text { constant for rough surface. }\end{array}$ \\
\hline$\gamma-\mathrm{Al}_{2} \mathrm{O}_{3}$ & R141b & [35] & $\begin{array}{l}0.001,0.01 \text { and } \\
0.1 \text { vol.\% }\end{array}$ & $\begin{array}{l}\text { BHT enhanced for nanoparticle } \\
\text { concentrations of } 0.001 \text { vol. } \%, 0.01 \\
\text { vol. } \% \text { and decreased with } 0.1 \text { vol. } \% \text {. }\end{array}$ \\
\hline $\mathrm{TiO}_{2}$ & $\mathrm{H}_{2} \mathrm{O}$ & [36] & $\mathrm{NiCr}$ wire & CHF increased up to $200 \%$ \\
\hline & $\mathrm{H}_{2} \mathrm{O}$ & [37] & $\begin{array}{l}0.000094-0.047 \\
\text { vol. } \%\end{array}$ & $\begin{array}{l}\text { HTC decreased, then improved. CHF } \\
\text { increased about } 91 \% \text {. }\end{array}$ \\
\hline & $\mathrm{H}_{2} \mathrm{O}$ & [38] & 0.0011 vol.\% & $\begin{array}{l}\text { HTC decreased. CHF increased about } \\
220 \% \text {. }\end{array}$ \\
\hline & R-141b & [13] & & CHF decreased. \\
\hline $\mathrm{ZnO}$ & EC & [39] & $0.5-3.7$ vol.\% & $\begin{array}{l}\text { HTC increased about } 22 \% \text { at } \\
\text { concentration of } 1.6 \% \text {. Maximum } \\
\text { enhancement of } \mathrm{CHF} \text { was found to be } \\
117 \% \text { at } \phi=2.6 \% \text {. }\end{array}$ \\
\hline & $\begin{array}{l}\mathrm{H}_{2} \mathrm{O}- \\
\mathrm{EC}\end{array}$ & [14] & 0.5 wt. \% & Both $\mathrm{HTC}$ and $\mathrm{CHF}$ increased. \\
\hline & $\begin{array}{l}\mathrm{H}_{2} \mathrm{O}- \\
E C\end{array}$ & [40] & $\begin{array}{l}0.025,0.05,0.075 \\
\text { and } 0.1 \text { vol. } \%\end{array}$ & $\begin{array}{l}\text { HTC increased up to } 12 \% \text { at } \\
\text { concentration of } 0.1 \text { vol. } \% \text {. CHF } \\
\text { enhance about } 29 \% \text {. }\end{array}$ \\
\hline $\mathrm{CuO}$ & Pentane & [41] & $\begin{array}{l}0.005 \% \text { and } \\
0.01 \%\end{array}$ & $\begin{array}{l}\text { HTC increased up to } 20-30 \% \text { for brass } \\
\text { surface and } 15-25 \% \text { at the nanoparticle } \\
\text { concentration of } 0.005 \% \text {. }\end{array}$ \\
\hline $\mathrm{Fe}_{3} \mathrm{O}_{4}$ & $\mathrm{H}_{2} \mathrm{O}$ & [42] & 0.1 vol.\% & HTC increased up to $43 \%$ \\
\hline $\mathrm{WO}_{3}$ & $\mathrm{H}_{2} \mathrm{O}$ & {$[15]$} & $\begin{array}{l}0.005 \%, 0.01 \% \\
\text { vol. }\end{array}$ & $\begin{array}{l}\text { HTC ratio was increased by about } \\
6.7 \% \text {. }\end{array}$ \\
\hline
\end{tabular}

Table 3: Summary of non-metal or non-metallic oxide with base fluids for pool boiling since 2003.

\begin{tabular}{|c|c|c|c|c|c|}
\hline \multirow[b]{2}{*}{$\begin{array}{l}\text { Enhancement } \\
\text { Medium }\end{array}$} & \multicolumn{2}{|c|}{ Nanofluids } & \multirow[b]{2}{*}{ Reference } & \multirow{2}{*}{$\begin{array}{l}\text { Condition } \\
\text { (Concentration/ } \\
\text { Heater type/ } \\
\text { NPs Size) }\end{array}$} & \multirow[b]{2}{*}{ Observation } \\
\hline & $\begin{array}{l}\text { Nano- } \\
\text { particles }\end{array}$ & $\begin{array}{l}\text { Base } \\
\text { fluid }\end{array}$ & & & \\
\hline \multirow{8}{*}{$\begin{array}{l}\text { Non-metal } \\
\text { and Non- } \\
\text { metallic } \\
\text { Oxide }\end{array}$} & \multirow{4}{*}{$\mathrm{SiO}_{2}$} & \multirow{3}{*}{$\mathrm{H}_{2} \mathrm{O}$} & [43] & $\mathrm{NiCr}$ wire & Constant BHT. CHF increased up to $60 \%$. \\
\hline & & & [44] & $\mathrm{NiCr}$ wire & $\begin{array}{l}\text { CHF enhanced greater than three times with } \\
\text { pure water. }\end{array}$ \\
\hline & & & [45] & $\mathrm{NiCr}$ wire & $\begin{array}{l}\mathrm{CHF} \text { enhanced up to } 50 \% \text { in } \mathrm{SiO}_{2} \\
\text { nanoparticles in water. }\end{array}$ \\
\hline & & $\begin{array}{l}\mathrm{EC} \\
\text { and } \\
\mathrm{H}_{2} \mathrm{O}\end{array}$ & [16] & $\begin{array}{l}0.25-1.00 \\
\text { vol. } \%\end{array}$ & $\begin{array}{l}\text { As the nanoparticle diameter decreased, the } \\
\text { HTC increased from } 84 \mathrm{~nm} \text { to } 120 \mathrm{~nm} \text {. }\end{array}$ \\
\hline & CNTs & $\begin{array}{l}\mathrm{H}_{2} \mathrm{O} \\
\text { and } \\
\mathrm{R}-22\end{array}$ & [46] & $\begin{array}{l}\text { Stainless steel } \\
\text { tube }\end{array}$ & $\begin{array}{l}\text { HTC was observed to increase up to } 28.7 \% \\
\text { at heat fluxes fewer than } 30 \mathrm{~kW} / \mathrm{m}^{2} \text {. }\end{array}$ \\
\hline & & $\mathrm{H}_{2} \mathrm{O}$ & [47] & $\begin{array}{l}0.01,0.1, \text { and } \\
0.3 \mathrm{~g} / 1\end{array}$ & CHF increased about 145 to $245 \%$. \\
\hline & \multirow[b]{2}{*}{ MWCNTS } & $\mathrm{H}_{2} \mathrm{O}$ & [48] & $0.01-0.1$ wt. $\%$ & $\begin{array}{l}\text { Depending on the types on chemical bond, } \\
\text { HTC can either increased or decreased. CHF } \\
\text { increased about } 274.2 \% \text {. }\end{array}$ \\
\hline & & $\mathrm{H}_{2} \mathrm{O}$ & [49] & $0.1-1$ wt. \% & $\begin{array}{l}\text { HTC increased to } 34.2 \% \text { for covalent } \\
\text { nanofluids and } 53.4 \% \text { for MWCNTs- } \\
\mathrm{COOH} \text { and MWCNTs-OH. Reduction of } \\
\text { nanofluids that were not covalent. }\end{array}$ \\
\hline
\end{tabular}


Table 4. Summary of nanoparticle mixture with base fluids for pool boiling since 2003.

\begin{tabular}{|c|c|c|c|c|c|}
\hline \multirow[b]{2}{*}{$\begin{array}{l}\text { Enhancement } \\
\text { Medium }\end{array}$} & \multicolumn{2}{|c|}{ Nanofluids } & \multirow[b]{2}{*}{ Reference } & \multirow{2}{*}{$\begin{array}{l}\text { Condition } \\
\text { (Concentration/ } \\
\text { Heater type/ } \\
\text { NPs Size) }\end{array}$} & \multirow[b]{2}{*}{ Observation } \\
\hline & $\begin{array}{l}\text { Nano- } \\
\text { particles }\end{array}$ & $\begin{array}{l}\text { Base } \\
\text { fluid }\end{array}$ & & & \\
\hline \multirow{8}{*}{$\begin{array}{l}\text { Nano } \\
\text { particle } \\
\text { mixture }\end{array}$} & & $\mathrm{H}_{2} \mathrm{O}$ & {$[50]$} & $\begin{array}{c}(<0.1 \text { vol. } \%) \\
\text { Stainless steel } \\
\text { plate }\end{array}$ & $\begin{array}{l}\text { BHT decreased. At low concentrations, } \mathrm{CHF} \\
\text { increased up to } 80 \% \text {. }\end{array}$ \\
\hline & $\begin{array}{c}\mathrm{Al}_{2} \mathrm{O}_{3} \\
\text { and } \mathrm{TiO}_{2}\end{array}$ & $\mathrm{H}_{2} \mathrm{O}$ & {$[51]$} & $\mathrm{NiCr}$ wire & CHF e increased up to $100 \%$. \\
\hline & $\begin{array}{l}\mathrm{Al}_{2} \mathrm{O}_{3} \text { and } \\
\mathrm{Bi}_{2} \mathrm{O}_{3}\end{array}$ & $\mathrm{H}_{2} \mathrm{O}$ & {$[52]$} & $\mathrm{NiCr}$ wire & $\begin{array}{l}\mathrm{CHF} \text { enhanced up to } 50 \% \text { for } \mathrm{Al}_{2} \mathrm{O}_{3} \text { and } \\
33 \% \text { for } \mathrm{Bi}_{2} \mathrm{O}_{3} \text {. With nanoparticle } \\
\text { concentration, } \mathrm{CHF} \text { increased for a certain } \\
\text { heat flux value. }\end{array}$ \\
\hline & $\begin{array}{l}\mathrm{LiBr} \text { and } \\
\mathrm{Al}_{2} \mathrm{O}_{3}\end{array}$ & $\mathrm{H}_{2} \mathrm{O}$ & [53] & $\begin{array}{c}\text { 0-0.1 vol.\% } \\
\text { distributed in } \\
\mathrm{H}_{2} \mathrm{O} / \mathrm{LiBr} \\
\text { solutions } \\
(3,7 \text { and10 } \\
\text { wt.\% of } \mathrm{LiBr}) \text {. }\end{array}$ & $\begin{array}{l}\mathrm{HTC} \text { decreased at volume friction. } \mathrm{CHF} \\
\text { increased about } 48.5 \% \text { with the } 0.1 \text { vol. } \% \\
\mathrm{Al}_{2} \mathrm{O}_{3} \text { in } 10 \text { wt. \% } \mathrm{LiBr} \text { aqueous solution. }\end{array}$ \\
\hline & $\begin{array}{l}\mathrm{ZnO}, \alpha- \\
\mathrm{Al}_{2} \mathrm{O}_{3} \text { and } \\
\text { MWCNTs }\end{array}$ & $\mathrm{H}_{2} \mathrm{O}$ & [17] & $\begin{array}{l}0.010 .02 \text { and } \\
0.05 w t . \%\end{array}$ & $\begin{array}{l}\mathrm{HTC} \text { decreased for both } \mathrm{ZnO} \text { and } \mathrm{Al}_{2} \mathrm{O}_{3} \text { but } \\
\text { MWCNTs improved it. }\end{array}$ \\
\hline & $\begin{array}{l}\mathrm{Al}_{2} \mathrm{O}_{3-} \\
\mathrm{SiO}_{2}\end{array}$ & $\mathrm{H}_{2} \mathrm{O}$ & [18] & 0.001 vol. \% & $\begin{array}{l}\text { At a very low concentration } \mathrm{HTC} \text { increased } \\
\text { noticeably for } \mathrm{Al}_{2} \mathrm{O}_{3} \text { nanofluid and } \\
\text { decreased for } \mathrm{SiO}_{2} \text { nanofluid. }\end{array}$ \\
\hline & $\begin{array}{l}\mathrm{TiO}_{2} \text { and } \\
\mathrm{MgO}\end{array}$ & $\mathrm{H}_{2} \mathrm{O}$ & [19] & $\begin{array}{l}130 \mathrm{~mm} \\
\text { diameter and } \\
205 \mathrm{~mm} \\
\text { height. }\end{array}$ & $\begin{array}{l}\mathrm{CHF} \text { increased in the range of } 10.51 \% \text { to } \\
52.42 \% \text { in case of } \mathrm{TiO}_{2} \text { and } 23 \% \text { to } 60.88 \% \\
\text { in case of } \mathrm{MgO} \text { nanofluid with increase in } \\
\text { volume fraction. }\end{array}$ \\
\hline & $\begin{array}{l}\mathrm{h}-\mathrm{BN} \text { and } \\
\mathrm{SiO}_{2}\end{array}$ & DCM & {$[10]$} & 1.0 vol. \% & $\begin{array}{l}\text { For } \mathrm{H}-\mathrm{BN} / \mathrm{DCM} \text { and } \mathrm{SiO}_{2} / \mathrm{DCM} \text {, } \mathrm{HTC} \text { were } \\
\text { observed to be } 27.59 \%, 14.44 \% \text { and } 20.69 \\
\% \text { and } 16.67 \% \text { for saturation boiling and } \\
\text { after-saturation boiling processes. }\end{array}$ \\
\hline
\end{tabular}

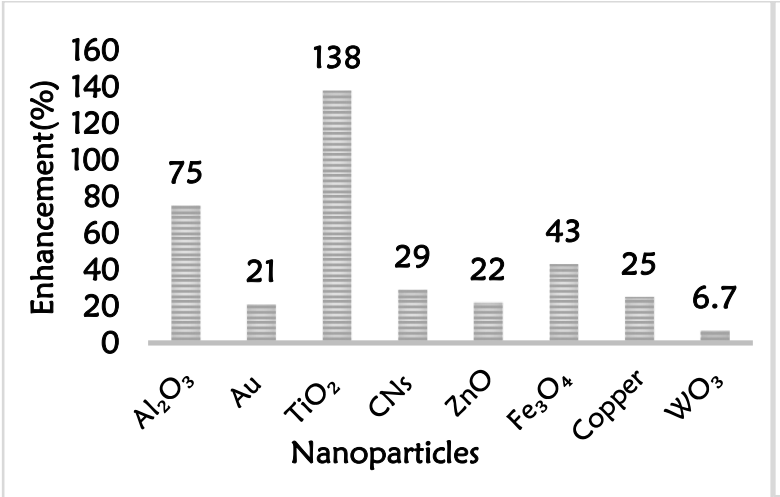

(a)

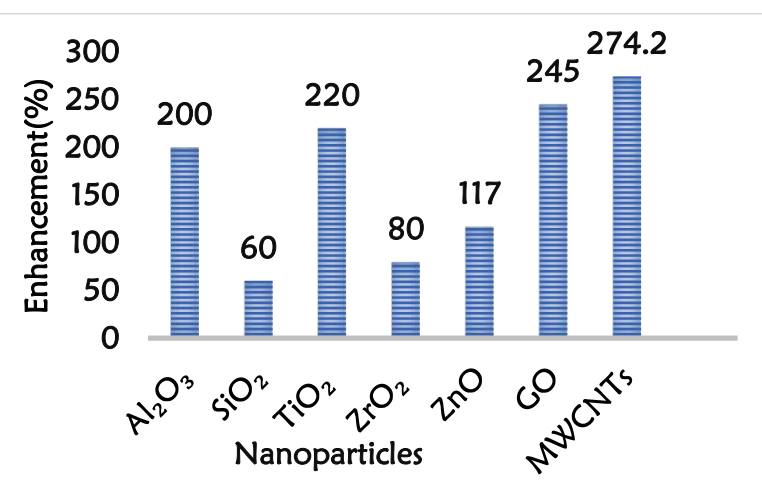

(b)

Figure 14: Bar chart to illustrate maximum increased (\%) of (a) HTC and (b) CHF in pool boiling for different nanoparticles. 


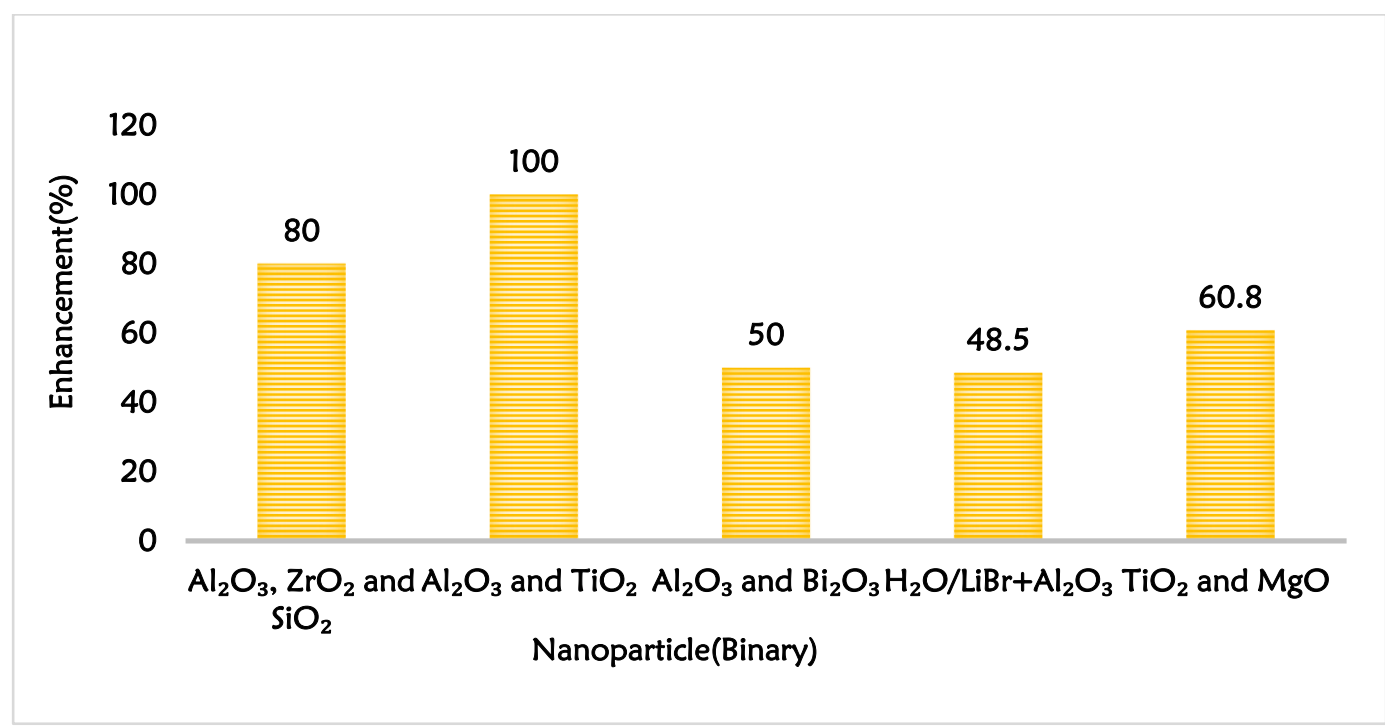

Figure 15: Bar chart to illustrate maximum increased (\%) of CHF in pool boiling for different binary nanoparticle.

Table 5: Summary of metal nanoparticle with base fluids for flow boiling since 2003.

\begin{tabular}{|c|c|c|c|c|c|}
\hline \multirow[b]{2}{*}{$\begin{array}{l}\text { Enhancement } \\
\text { Medium }\end{array}$} & \multicolumn{2}{|c|}{ Nanofluids } & \multirow[b]{2}{*}{ Reference } & \multirow{2}{*}{$\begin{array}{l}\text { Condition } \\
\text { (Concentration/ } \\
\text { Heater type/Geometry (flow } \\
\text { nature)/NPs diameter (nm)) }\end{array}$} & \multirow[b]{2}{*}{ Observation } \\
\hline & $\begin{array}{l}\text { Nano- } \\
\text { particles }\end{array}$ & $\begin{array}{l}\text { Base } \\
\text { fluid }\end{array}$ & & & \\
\hline Metal & Copper & $\mathrm{H}_{2} \mathrm{O}$ & [54] & $\begin{array}{l}50 \mathrm{~nm} \text { parallel minichannels of } \\
\mathrm{dh}=800 \mu \mathrm{m} .\end{array}$ & $\begin{array}{l}\text { With increasing nanoparticle } \\
\text { concentration, BHT } \\
\text { enhanced. }\end{array}$ \\
\hline
\end{tabular}

Table 6: Summary of metal oxide nanoparticle with base fluids for flow boiling since 2003.

\begin{tabular}{|c|c|c|c|c|c|}
\hline \multirow{2}{*}{$\begin{array}{l}\text { Enhance } \\
\text { ment } \\
\text { Medium }\end{array}$} & \multicolumn{2}{|c|}{ Nanofluids } & \multirow{2}{*}{$\begin{array}{l}\text { Refe } \\
\text { renc } \\
\text { e }\end{array}$} & \multirow{2}{*}{$\begin{array}{l}\text { Condition(Concentratio } \\
\text { n/Heater type/ } \\
\text { Geometry(flow nature)/ } \\
\text { NPs diameter (nm) }\end{array}$} & \multirow[b]{2}{*}{ Observation } \\
\hline & $\begin{array}{l}\text { Nano- } \\
\text { particle }\end{array}$ & $\begin{array}{l}\text { Base } \\
\text { fluid }\end{array}$ & & & \\
\hline \multirow{7}{*}{$\begin{array}{l}\text { Metal } \\
\text { Oxide }\end{array}$} & & $\mathrm{H}_{2} \mathrm{O}$ & {$[55]$} & $\begin{array}{c}0.01 \\
\text { vol. } \%, D i=6.35 \mathrm{~mm} \\
D_{0}=12.78 \mathrm{~mm}, L=0.5 \mathrm{~m} \\
\text { Thickness }=0.9 \mathrm{~mm}\end{array}$ & $\begin{array}{l}\text { CHF enhancement about to } 70 \% \text { at low } \\
\text { concentration of the nanoparticle. }\end{array}$ \\
\hline & & $\mathrm{H}_{2} \mathrm{O}$ & {$[56]$} & $\begin{array}{l}0.2 \text { wt. } \%, \mathrm{NP} \\
\text { dia }=40 \mathrm{~nm}\end{array}$ & HTC increased by $17 \%$. \\
\hline & & $\mathrm{H}_{2} \mathrm{O}$ & {$[57]$} & $\begin{array}{l}0.001,0.005 \text { and } \\
0.01 w t . \%\end{array}$ & $\begin{array}{l}\text { At a given mass flux, HTC increased up to } \\
27.97 \% \text {. }\end{array}$ \\
\hline & & $\mathrm{H}_{2} \mathrm{O}$ & {$[20]$} & $0.01-5$ vol. $\%$ & $\begin{array}{l}\text { With nanoparticle concentration, HTC } \\
\text { increased in single-phase and decreased in } \\
\text { compressed liquid flow area. }\end{array}$ \\
\hline & & $\mathrm{H}_{2} \mathrm{O}$ & {$[58]$} & 0.15 wt. $\%$ & $\begin{array}{l}\text { At } 0.15 \text { wt. } \% \text { and } \mathrm{Re}=13500 \text {, the overall } \\
\text { increase in the HTC was } 35.7 \% \text {, but the HTC } \\
\text { nanofluids decreased over time. }\end{array}$ \\
\hline & \multirow[b]{2}{*}{$\mathrm{ZnO}$} & $\mathrm{H}_{2} \mathrm{O}$ & {$[21]$} & 0.005-0.02 vol.\% & $\begin{array}{l}\text { Heat transfer rate of } \mathrm{Al}_{2} \mathrm{O}_{3} / \mathrm{H}_{2} \mathrm{O} \text { nanofluid was } \\
\text { increased by flow boiling by roughly } 86 \% \text {. }\end{array}$ \\
\hline & & $\mathrm{H}_{2} \mathrm{O}$ & {$[22]$} & $\begin{array}{c}0.0001-0.1 \text { vol. } \% ; N P s \\
\text { diameter }<100(30-50) \\
n m\end{array}$ & $\begin{array}{l}\text { At higher concentration HTC increased by } \\
126 \% \text {. }\end{array}$ \\
\hline
\end{tabular}




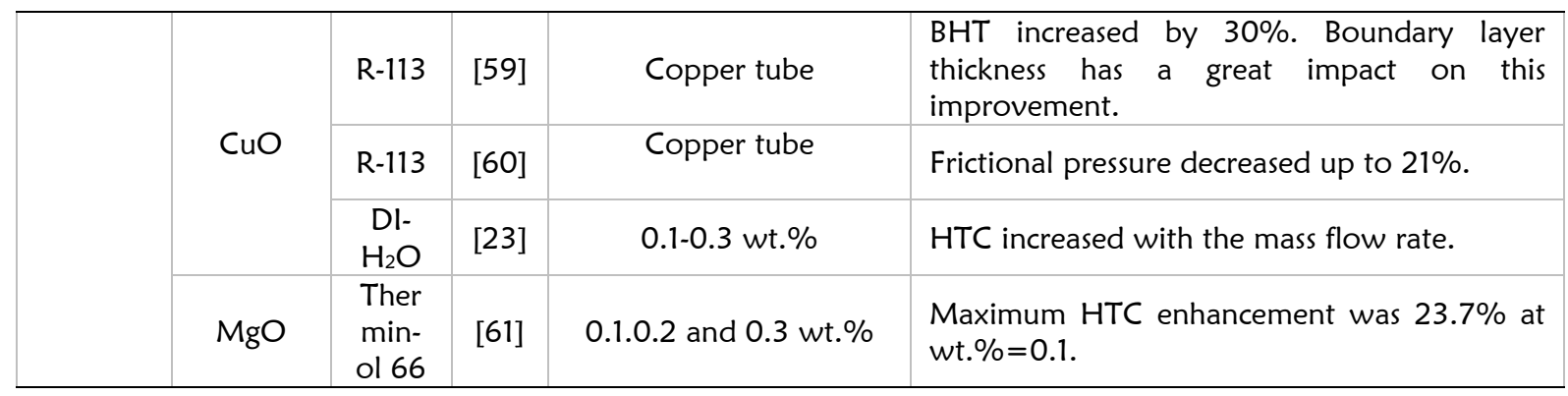

Table 7: Summary of non metal and nonmetallic oxide nanoparticle with base fluids for flow boiling since 2003.

\begin{tabular}{|c|c|c|c|c|c|}
\hline \multirow{2}{*}{$\begin{array}{c}\text { Enhancement } \\
\text { Medium }\end{array}$} & \multicolumn{2}{|c|}{ Nanofluids } & \multirow[t]{2}{*}{ Reference } & \multirow{2}{*}{$\begin{array}{c}\text { Condition } \\
\text { (Concentration/Heater } \\
\text { type/Geometry (flow } \\
\text { nature)/NPs diameter } \\
(\mathrm{nm})\end{array}$} & \multirow[t]{2}{*}{ Observation } \\
\hline & $\begin{array}{l}\text { Nano- } \\
\text { particles }\end{array}$ & $\begin{array}{l}\text { Base } \\
\text { fluid }\end{array}$ & & & \\
\hline \multirow{2}{*}{$\begin{array}{l}\text { Non-metal } \\
\text { and Non- } \\
\text { metallic } \\
\text { Oxide }\end{array}$} & Ceramic & $\mathrm{H}_{2} \mathrm{O}$ & [24] & $0.1-0.5$ vol. $\%$ & $\begin{array}{l}\text { Modest increase in the overall } \\
\text { nanofluid heat transfer rate. }\end{array}$ \\
\hline & GO & $\mathrm{H}_{2} \mathrm{O}$ & {$[62]$} & 0.01 vol. \% & CHF increased about $100 \%$. \\
\hline
\end{tabular}

Table 8: Summary of nanoparticle mixture with base fluids for flow boiling since 2003.

\begin{tabular}{|c|c|c|c|c|c|}
\hline \multirow[b]{2}{*}{$\begin{array}{l}\text { Enhancement } \\
\text { Medium }\end{array}$} & \multicolumn{2}{|c|}{ Nanofluids } & \multirow[b]{2}{*}{ Reference } & \multirow{2}{*}{$\begin{array}{c}\text { Condition } \\
\text { (Concentration/Heater } \\
\text { type/Geometry (flow } \\
\text { nature)/NPs diameter } \\
(\mathrm{nm}) \\
\end{array}$} & \multirow[b]{2}{*}{ Observation } \\
\hline & $\begin{array}{l}\text { Nano- } \\
\text { particles }\end{array}$ & $\begin{array}{l}\text { Base } \\
\text { fluid }\end{array}$ & & & \\
\hline \multirow{8}{*}{$\begin{array}{l}\text { Nano- } \\
\text { particle } \\
\text { mixture }\end{array}$} & $\begin{array}{l}\mathrm{Al}_{2} \mathrm{O}_{3} \text { and } \\
\mathrm{TiO}_{2}\end{array}$ & $\mathrm{H}_{2} \mathrm{O}$ & {$[25]$} & $\begin{array}{l}\text { 0.1-2.5 vol.\%.NP } \\
\text { diameter }=20,40 \mathrm{~nm}\end{array}$ & $\begin{array}{l}\text { Deteriorated in both directions } \\
\text { with increasing nanoparticle } \\
\text { concentration. }\end{array}$ \\
\hline & $\begin{array}{l}\text { SiC and } \\
\text { Graphite }\end{array}$ & $\mathrm{H}_{2} \mathrm{O}$ & [26] & $0.1 v o l . \%$ & $\begin{array}{l}\text { At } 0.1 \text { vol. } \% \text { SiC/ } \mathrm{H}_{2} \mathrm{O} \text { and } \\
\text { Graphite } / \mathrm{H}_{2} \mathrm{O} \text { nanofluid } \mathrm{BHT} \\
\text { increased. }\end{array}$ \\
\hline & $\begin{array}{l}\mathrm{Al}_{2} \mathrm{O}_{3} \\
\mathrm{ZnO}, \text { and } \\
\text { Diamond }\end{array}$ & $\mathrm{H}_{2} \mathrm{O}$ & {$[63]$} & $\begin{array}{c}\leq 0.1 \text { vol. } \%, N P \\
\text { dia }=30 \mathrm{~nm}\end{array}$ & $\begin{array}{l}\text { BHT increased marginally at low } \\
\text { heat flux. CHF increased up to } \\
53 \% \text {. }\end{array}$ \\
\hline & $\begin{array}{l}\mathrm{Al}_{2} \mathrm{O}_{3} \text { and } \\
\quad \mathrm{SiC}\end{array}$ & $\mathrm{H}_{2} \mathrm{O}$ & [64] & $\begin{array}{l}0.01 \mathrm{Vol} . \% . \mathrm{Al}_{2} \mathrm{O}_{3} \\
\text { lower than } 50 \mathrm{~nm} \text { and } \\
\mathrm{SiC} \text { higher than } 50 \mathrm{~nm}\end{array}$ & $\begin{array}{l}\text { CHF increased for both } \\
\text { nanofluids. }\end{array}$ \\
\hline & $\mathrm{Al}_{2} \mathrm{O}_{3}-\mathrm{Cu}$ & $\mathrm{H}_{2} \mathrm{O}$ & {$[65]$} & $\begin{array}{l}\text { Uniformly heated } \\
\text { tube. }\end{array}$ & CHF increased about $13 \%$. \\
\hline & $\begin{array}{l}\mathrm{Fe}_{3} \mathrm{O}_{4} \text { and } \\
\mathrm{Al}_{2} \mathrm{O}_{3}\end{array}$ & $\mathrm{H}_{2} \mathrm{O}$ & {$[66]$} & $\begin{array}{l}0.0001,0.001 \text { vol. } \% \\
\text { NP diameter }=25 \mathrm{~nm}\end{array}$ & $\begin{array}{l}\text { CHF increased for magnetic } \\
\text { nanofluid. }\end{array}$ \\
\hline & $\begin{array}{l}\text { MWCNTs, } \\
\mathrm{CuO} \text { and } \\
\mathrm{Al}_{2} \mathrm{O}_{3}\end{array}$ & $\mathrm{H}_{2} \mathrm{O}$ & {$[67]$} & $\begin{array}{l}0.1-0.3 \text { wt. } \%, 12-14 \mathrm{~nm} \\
\times 1.5-2 \mu \mathrm{m} \text { for } \\
\text { MWCNT and 50nm } \\
\text { for metal oxide }\end{array}$ & $\begin{array}{l}\text { HTC increased for MWCNTs and } \\
\text { increased then deteriorated for } \\
\text { metal oxide particles. }\end{array}$ \\
\hline & $\begin{array}{l}\mathrm{AIN} \text { and } \\
\mathrm{Al}_{2} \mathrm{O}_{3}\end{array}$ & $\mathrm{H}_{2} \mathrm{O}$ & {$[68]$} & $\begin{array}{l}0.1-0.5 \text { vol.\%.NP } \\
\text { diameter } 20 \mathrm{~nm} \text { for }\end{array}$ & $\begin{array}{l}\text { HTC depends on some parameter } \\
\text { according to new saturated flow } \\
\text { boiling correlation proposed. }\end{array}$ \\
\hline
\end{tabular}




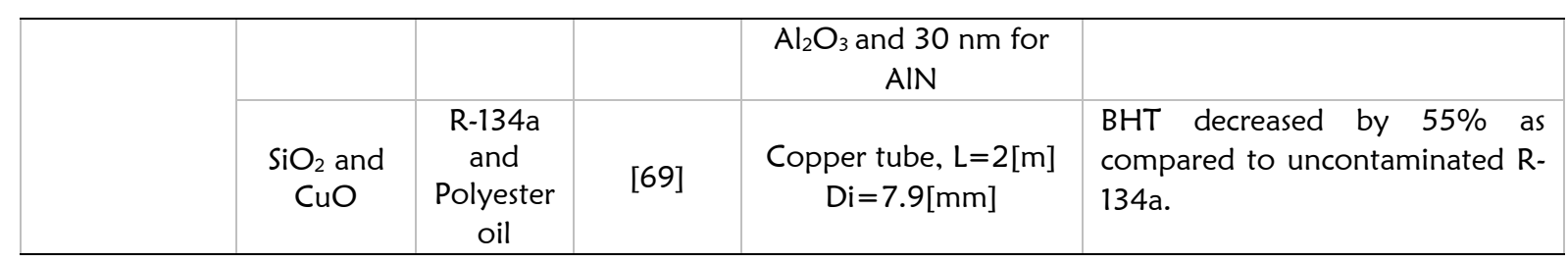

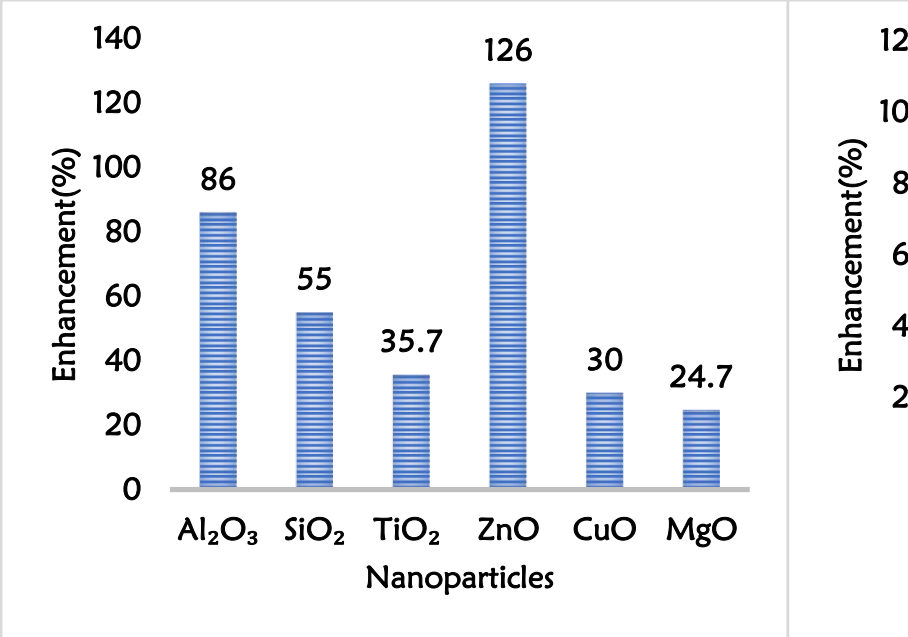

(a)

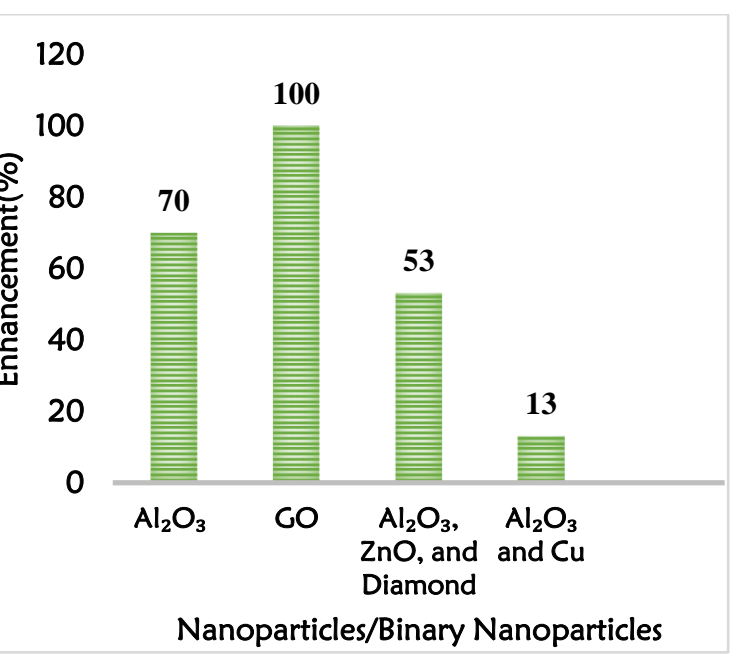

(b)

Figure 16: Bar chart to illustrate maximum increased (\%) (a) HTC (b) CHF in flow boiling for different nanoparticles or binary nanoparticles.

\section{RECOMMENDATION AND FUTURE DIRECTION}

Many researchers are still working on detailed research on the boiling heat transfer rate of nanofluids. After reviewing several articles on nanofluids boiling heat transfer, it has seen that the heat transfer coefficient and critical heat flux could be increased by using nanofluids in the boiling heat transfer. This improved heat transfer coefficient and critical heat flux can be implemented in the design of heat exchangers and heat storage systems. Therefore, the effects of nanofluids on the enhancement of boiling heat transfer have great importance in industrial applications such as cooling of nuclear reactors, cooling of high-power electronics components, heat exchangers. While conducting the experiment, the researchers usually varied the concentration of the nanoparticles and had found different results on both HTC and CHF. But they are unable to give any mathematical relations between nanoparticle concentration with HTC and CHF. In the future, the findings of the present research can help the researchers to concentrate on formulating the mathematical relations and can also open a door of opportunity in the field of heat transfer enhancement.

\section{CONCLUSIONS}

Nowadays the applications of nanoparticles in heat transfer have been increased due to its better thermophysical properties. In this paper, the authors have tried to show the progress of research on the boiling heat transfer of nanofluids. Nanofluids have large influence on the performance of pool and flow boiling heat transfer. It can either enhance or reduce the HTC and CHF. It mainly depends on several important factors. From the total summary, it can be concluded that.

1. In comparison with the base fluids, most of the nanofluids show an increased HTC and CHF and increased dramatically with rising nanoparticle concentrations. With decreasing nanoparticle size, the heat transfer coefficient increases.

2. In case of pool boiling the research papers gives their results equally on HTC enhancement as well as the $\mathrm{CHF}$ enhancement, whereas in the case of flow boiling just a few results have been found for CHF enhancement.

3. Researchers have investigated the boiling enhancement with the various nanoparticles. Among those nanoparticles, the widely used nanoparticles are $\mathrm{Al}_{2} \mathrm{O}_{3}$ and $\mathrm{TiO}_{2}$. Between these two, $\mathrm{Al}_{2} \mathrm{O}_{3}$ is the most widely used nanoparticles for the enhancement of pool and flow boiling heat transfer. In the case of binary nanoparticles, the most widely used combination is $\mathrm{Al}_{2} \mathrm{O}_{3}$ and $\mathrm{TiO}_{2}$. 
4. Nanofluids boiling heat transfer activity depends on different variables as shown in figure 17 which includes the thermophysical characteristics of nanofluids, mutual interactions, type of the heating surfaces, type of coatings in the plate, type of nanoparticles, the concentration of the nanoparticle (by volume and mass), size of the nanoparticle, heat and mass fluxes, pressure system, vapor quality and additives, etc.

5. In the case of pool boiling the maximum increased heat transfer coefficient is found as $138 \%$ for $\mathrm{TiO}_{2}$ nanoparticles and the maximum increased critical heat flux is found as $274.2 \%$ for MWCNTs.

6. In the case of flow boiling the maximum increased HTC is found as $126 \%$ for $\mathrm{ZnO}$ nanoparticles and the maximum increased critical heat flux is found as $100 \%$ for $\mathrm{GO}$ nanoparticles.

7. When two or more nanoparticles in succession or binary nanofluids are used the CHF in pool boiling increased up to $100 \%$ for $\mathrm{Al}_{2} \mathrm{O}_{3}$ and $\mathrm{TiO}_{2}$. Also, the $\mathrm{CHF}$ in flow boiling increased up to $53 \%$ for $\mathrm{Al}_{2} \mathrm{O}_{3}, \mathrm{ZnO}$, and Diamond.

8. Binary nanofluids are superior CHF for both pool and flow boiling rather than HTC.

9. Further work will be needed in order to find more suitable nanofluids for BHT as the findings of various researchers are not constant. So, testing more and more nanoparticles are essential.

10. To make applicable nanofluids, stability is the most important thing. It should thus be examined and developed for both steady and flow conditions in nanofluids boiling.

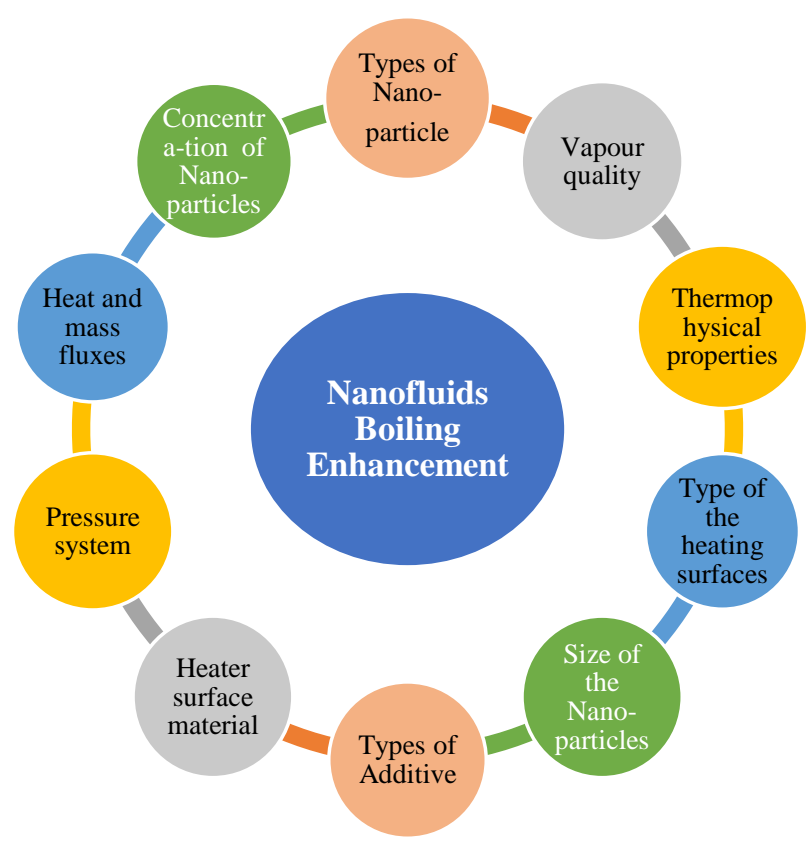

Figure 17: Factors affecting nanofluid boiling heat transfer enhancement.

\section{REFERENCES}

1. Al-Sukaini, B. Q. A. (2014). Enhancement Techniques of Boiling Heat Transfer.

2. Şeşen, M., Tekşen, Y., Şahin, B., Şendur, K., Pınar Mengüç, M., \& Koşar, A. (2013). Boiling heat transfer enhancement of magnetically actuated nanofluids. Applied Physics Letters, 102(16), 163107. https:// doi: $10.1063 / 1.4802791$

3. Bianco, V., Manca, O., Nardini, S., and Vafai,K. (2015). Heat Transfer Enhancement with Nanofluids. CRC Press Taylor and Francis Group.

4. Rathore, M.M. (2015). Engineering Heat and Mass Transfer. Third Edition. University Science Press Publications.

5. Cengel, Y. A., and Ghajar, A.J. (2015). Heat and Mass Transfer. Fundamentals and applications. Sixth Edition McGraw-Hill Publications.

6. Kreith, F., Manglik, R.M., and Bohn, M.S. (2010). Principles of Heat Transfer. Seventh Edition. Cengage Learning Publications.

7. Mali, S., Pise, A., \& Acharya, A. (2014). Review on flow boiling heat transfer enhancement with nanofluids. IOSR J. Mech. Civ. Eng, 11, 43-48.

8. Boda, M. A., Deshetti, M. R. S., \& Gavade, M. A. (2017). Advanced Heat Transfer Enhancement by using Nanofluids: A Review. International Journal of Engineering Trends and Technology (IJETT)-Volume-45 Number-8-March. DOI: 10.14445/22315381/IJETT-V45P279 
9. Kamel, M. S., Syeal, R. A., \& Abdulhussein, A. A. (2016). Heat transfer enhancement using nanofluids: a review of the recent literature. American Journal of Nano Research and Applications, 4(1), 1-5. doi: 10.11648/j.nano.20160401.11

10. Çiftçi, E., \& Sözen, A. (2020). Heat transfer enhancement in pool boiling and condensation using h-BN/DCM and SiO2/DCM nanofluids: experimental and numerical comparison. International Journal of Numerical Methods for Heat \& Fluid Flow. https://doi.org/10.1108/HFF-02-2020-0113

11. Ham, J., \& Cho, H. (2016). Theoretical analysis of pool boiling characteristics of Al2O3 nanofluid according to volume concentration and nanoparticle size. Applied Thermal Engineering, 108, 158-171. http://doi.org/10.1016/j.applthermaleng.2016.07.058

12. Sujun, D. O. N. G., Jiang, H., Yongqi, X. I. E., Xiaoming, W. A. N. G., Zhongliang, H. U., \& Jun, W. A. N. G. (2019). Experimental investigation on boiling heat transfer characteristics of Al2O3-water nanofluids in swirl microchannels subjected to an acceleration force. Chinese Journal of Aeronautics, 32(5), 1136-1144. https://doi.org/10.1016/j.cja.2019.01.016

13. Khliyeva, O., Lukianova, T., Semenyuk, Y., Zhelezny, V., \& Nikulin, A. (2018). An experimental study of the effect of nanoparticle additives to the refrigerant R141b on the pool boiling process. Восточно-Европейский журнал передовых технологий, (4 (8)), 59-66. DOI: 10.15587/1729-4061.2018.139418

14. Sarafraz, M. M., Pourmehran, O., Nikkhah, V., \& Arya, A. (2018). Pool boiling heat transfer to zinc oxideethylene glycol nano-suspension near the critical heat flux. Journal of Mechanical Science and Technology, 32(5), 2309-2315. https://doi.org/10.1007/s12206-018-0442-z

15. Kamel, M. S., \& Lezsovits, F. (2020). Experimental Investigation on Pool Boiling Heat Transfer Performance Using Tungsten Oxide WO3 Nanomaterial-Based Water Nanofluids. Materials, 13(8), 1922. https://doi.org/10.3390/ma13081922

16. Hu, Y., Li, H., He, Y., Liu, Z., \& Zhao, Y. (2017). Effect of nanoparticle size and concentration on boiling performance of $\mathrm{SiO} 2$ nanofluid. International Journal of Heat and Mass Transfer, 107, 820-828. https://doi.org/10.1016/j.ijheatmasstransfer.2016.11.090

17. Shoghl, S. N., Bahrami, M., \& Jamialahmadi, M. (2017). The boiling performance of $\mathrm{ZnO}, \alpha-\mathrm{Al} 2 \mathrm{O} 3$ and MWCNTs/water nanofluids: An experimental study. Experimental Thermal and Fluid Science, 80, 27-39. https://doi.org/10.1016/j.expthermflusci.2016.07.024

18. Aizzat, M. A. H., Sulaiman, M. Z., Enoki, K., \& Okawa, T. (2019). Heat transfer coefficient of nucleate boiling in low concentration level of single and hybrid Al2O3-SiO2 water-based nanofluids. In IOP Conference Series: Materials Science and Engineering (Vol. 469, No. 1, p. 012109). IOP Publishing. https://doi:10.1088/1757-899X/469/1/012109

19. Sapre,G., and Kumarappa, D.S.(2017).Experimental Studies on Pool Boiling Heat Transfer using Titanium Oxide and Magnesium Oxide Nanofluids. International Journal of Innovative Research in Science, Engineering and Technology.

20. Sudheer, S. V. S., \& Balasubramanian, K. (2019). Experimental studies of heat transfer and flow regimes during flow boiling of water and alumina nanofluids at different heat and mass fluxes. Proceedings of the Institution of Mechanical Engineers, Part C: Journal of Mechanical Engineering Science, 233(19-20), 7155-7169. https://doi.org/10.1177/0954406219866876

21. Wang, Y., \& Wu, J. M. (2015). Numerical simulation on single bubble behavior during $\mathrm{Al} 2 \mathrm{O} 3 / \mathrm{H} 2 \mathrm{O}$ nanofluids flow boiling using Moving Particle Simi-implicit method. Progress in Nuclear Energy, 85, 130-139. https://doi.org/10.1016/j.pnucene.2015.06.017

22. Prajapati, O. S., \& Rohatgi, N. (2014). Flow boiling heat transfer enhancement by using ZnO-Water nanofluids. Science and Technology of Nuclear Installations, 2014. https://doi.org/10.1155/2014/890316

23. Sarafraz, M. M., \& Hormozi, F. (2014). Scale formation and subcooled flow boiling heat transfer of CuO-water nanofluid inside the vertical annulus. Experimental Thermal and Fluid Science, 52, 205-214. https://doi.org/10.1016/j.expthermflusci.2013.09.012

24. Sarafraz, M. M., Arya, H., Saeedi, M., \& Ahmadi, D. (2018). Flow boiling heat transfer to MgO-therminol 66 heat transfer fluid: experimental assessment and correlation development. Applied Thermal Engineering, 138, 552-562. https://doi.org/10.1016/j.applthermaleng.2018.04.075

25. Nakhjavani, S., \& Zadeh, A. A. (2020). Flow boiling heat transfer characteristics of Titanium Oxide/Water Nanofluid (TIO2/DI Water) in an annular heat exchanger. Journal of Thermal Engineering, 6(4), 592-603.

26. Wang, Y., Deng, K., Wu, J. M., Su, G., \& Qiu, S. (2020). A mechanism of heat transfer enhancement or deterioration of nanofluid flow boiling heat transfer. International Journal of Heat and Mass Transfer, 158, 119985. https://doi.org/10.1016/j.ijheatmasstransfer.2020.119985

27. Witharana, S. (2003). Boiling of refrigerants on enhanced surfaces and boiling of nanofluids (Doctoral dissertation, Energiteknik).

28. You, S. M., Kim, J. H., \& Kim, K. H. (2003). Effect of nanoparticles on critical heat flux of water in pool boiling heat transfer. Applied physics letters, 83(16), 3374-3376. https://doi.org/10.1063/1.1619206

29. Wen, D., \& Ding, Y. (2005). Experimental investigation into the pool boiling heat transfer of aqueous based $y$ alumina nanofluids. Journal of Nanoparticle Research, 7(2), 265-274. https://doi.org/10.1007/s11051-005$3478-9$ 
30. Bang, I. C., \& Chang, S. H. (2005). Boiling heat transfer performance and phenomena of Al2O3-water nanofluids from a plain surface in a pool. International Journal of Heat and Mass Transfer, 48(12), 2407-2419. https://doi.org/10.1016/j.ijheatmasstransfer.2004.12.047

31. Coursey, J. S., \& Kim, J. (2008). Nanofluid boiling: The effect of surface wettability. International Journal of Heat and Fluid Flow, 29(6), 1577-1585. https://doi.org/10.1016/j.ijheatfluidflow.2008.07.004

32. Hojjat, M., Etemad, S. G., \& Bagheri, R. (2010). Laminar heat transfer of non-Newtonian nanofluids in a circular tube. Korean Journal of Chemical 1391-1396. https://doi.org/10.1016/j.icheatmasstransfer.2009.08.005

33. Raveshi, M. R., Keshavarz, A., Mojarrad, M. S., \& Amiri, S. (2013). Experimental investigation of pool boiling heat transfer enhancement of alumina-water-ethylene glycol nanofluids. Experimental Thermal and Fluid Science, 44, 805-814. https://doi.org/10.1016/j.expthermflusci.2012.09.025

34. Tang, X., Zhao, Y. H., \& Diao, Y. H. (2014). Experimental investigation of the nucleate pool boiling heat transfer characteristics of $\delta$-Al2O3-R141b nanofluids on a horizontal plate. Experimental Thermal and Fluid Science, 52, 88-96. https://doi.org/10.1016/j.expthermflusci.2013.08.025

35. Kim, H., Kim, J., \& KIM, M. (2006). experimental study on CHP (Characteristics of Water-TiO $\mathrm{Nano}_{2}$ fluids. Nuclear engineering and technology, 38(1).

36. Okawa, T., Takamura, M., \& Kamiya, T. (2012). Boiling time effect on CHF enhancement in pool boiling of nanofluids. International Journal of Heat and Mass Transfer, 55(9-10), 2719-2725. https://doi.org/10.1016/j.ijheatmasstransfer.2012.01.013

37. Mori, S., \& Okuyama, K. (2009). Enhancement of the critical heat flux in saturated pool boiling using honeycomb porous media. International Journal of Multiphase Flow, 35(10), 946-951. https://doi.org/10.1016/j.ijmultiphaseflow.2009.05.003

38. Kole, M., \& Dey, T. K. (2012). Investigations on the pool boiling heat transfer and critical heat flux of $\mathrm{ZnO}$ ethylene glycol nanofluids. Applied Thermal Engineering, 37, 112-119. https://doi.org/10.1016/j.applthermaleng.2011.10.066

39. Sarafraz, M. M., Kiani, T., \& Hormozi, F. (2016). Critical heat flux and pool boiling heat transfer analysis of synthesized zirconia aqueous nano-fluids. International Communications in Heat and Mass Transfer, 70, 7583. https://doi.org/10.1016/j.icheatmasstransfer.2015.12.008

40. Umesh, V., \& Raja, B. (2015). A study on nucleate boiling heat transfer characteristics of pentane and CuOpentane nanofluid on smooth and milled surfaces. Experimental Thermal and Fluid Science, 64, 23-29. https://doi.org/10.1016/j.expthermflusci.2015.01.016

41. Abdollahi, A., Salimpour, M. R., \& Etesami, N. (2017). Experimental analysis of magnetic field effect on the pool boiling heat transfer of a ferrofluid. Applied Thermal Engineering, 111, 1101-1110. https://doi.org/10.1016/j.applthermaleng.2016.10.019

42. Vassallo, P., Kumar, R., \& D’Amico, S. (2004). Pool boiling heat transfer experiments in silica-water nanofluids. International Journal of Heat and Mass Transfer, 47(2), 407-411. https://doi.org/10.1016/S00179310(03)00361-2

43. Milanova, D., \& Kumar, R. (2005). Role of ions in pool boiling heat transfer of pure and silica nanofluids. Applied Physics Letters, 87(23), 233107. https://doi.org/10.1063/1.2138805

44. Milanova, D., \& Kumar, R. (2008). Heat transfer behavior of silica nanoparticles in pool boiling experiment. Journal of Heat Transfer, 130(4). https://doi.org/10.1115/1.2787020

45. Park, K. J., \& Jung, D. (2007). Enhancement of nucleate boiling heat transfer using carbon nanotubes. International Journal of Heat and Mass Transfer, 50(21-22), 4499-4502. https://doi.org/10.1016/j.ijheatmasstransfer.2007.03.012

46. Kamatchi, R., Venkatachalapathy, S., \& Nithya, C. (2016). Experimental investigation and mechanism of critical heat flux enhancement in pool boiling heat transfer with nanofluids. Heat and Mass Transfer, 52(11), 2357 2366. https://doi.org/10.1007/s00231-015-1749-2

47. Amiri, A., Shanbedi, M., Amiri, H., Heris, S. Z., Kazi, S. N., Chew, B. T., \& Eshghi, H. (2014). Pool boiling heat transfer of CNT/water nanofluids. Applied Thermal Engineering, 71(1), 450-459. https://doi.org/10.1016/j.applthermaleng.2014.06.064

48. Xing, M., Yu, J., \& Wang, R. (2016). Effects of surface modification on the pool boiling heat transfer of MWNTs/water nanofluids. International Journal of Heat and Mass Transfer, 103, 914-919. https://doi.org/10.1016/j.ijheatmasstransfer.2016.07.053

49. Kim, S. J., Bang, I. C., Buongiorno, J., \& Hu, L. W. (2007). Surface wettability change during pool boiling of nanofluids and its effect on critical heat flux. International Journal of Heat and Mass Transfer, 50(19-20), 4105-4116. https://doi.org/10.1016/j.ijheatmasstransfer.2007.02.002

50. Kim, H. D., Kim, J., \& Kim, M. H. (2007). Experimental studies on CHF characteristics of nano-fluids at pool boiling. International journal of multiphase flow, 33(7), 691-706. https://doi.org/10.1016/j.ijmultiphaseflow.2007.02.007

51. Golubovic, M. N., Hettiarachchi, H. M., Worek, W. M., \& Minkowycz, W. J. (2009). Nanofluids and critical heat flux, experimental and analytical study. Applied Thermal Engineering, 29(7), 1281-1288. https://doi.org/10.1016/j.applthermaleng.2008.05.005 
52. Jung, J. Y., Kim, E. S., Nam, Y., \& Kang, Y. T. (2013). The study on the critical heat flux and pool boiling heat transfer coefficient of binary nanofluids $\left(\mathrm{H}_{2} \mathrm{O} / \mathrm{LiBr}+\mathrm{Al}_{2} \mathrm{O}_{3}\right)$. International journal of refrigeration, 36(3), 1056-1061. https://doi.org/10.1016/j.ijrefrig.2012.11.021

53. Boudouh, M., Gualous, H. L., \& De Labachelerie, M. (2010). Local convective boiling heat transfer and pressure drop of nanofluid in narrow rectangular channels. Applied Thermal Engineering, 30(17-18), 2619-2631. https://doi.org/10.1016/j.applthermaleng.2010.06.027

54. Lee, J., \& Mudawar, I. (2007). Assessment of the effectiveness of nanofluids for single-phase and two-phase heat transfer in micro-channels. International Journal of Heat and Mass Transfer, 50(3-4), 452-463. https://doi:10.1016/j.ijheatmasstransfer.2006.08.001

55. Kim, T. I., Jeong, Y. H., \& Chang, S. H. (2010). An experimental study on CHF enhancement in flow boiling using $\mathrm{Al} 2 \mathrm{O} 3$ nano-fluid. International Journal of Heat and Mass Transfer, 53(5-6), 1015-1022. https://doi.org/10.1016/j.ijheatmasstransfer.2009.11.011

56. Wang, Y., \& Su, G. H. (2016). Experimental investigation on nanofluid flow boiling heat transfer in a vertical tube under different pressure conditions. Experimental Thermal and Fluid Science, 77, 116-123. https://doi.org/10.1016/j.expthermflusci.2016.04.014

57. Abedini, E., Behzadmehr, A., Rajabnia, H., Sarvari, S. M. H., \& Mansouri, S. H. (2013). Experimental investigation and comparison of subcooled flow boiling of $\mathrm{TiO} 2$ nanofluid in a vertical and horizontal tube. Proceedings of the Institution of Mechanical Engineers, Part C: Journal of Mechanical Engineering Science, 227(8), 1742-1753. https://doi.org/10.1177/0954406212466765

58. Aminfar, H., Mohammadpourfard, M., \& Maroofiazar, R. (2014). Experimental study on the effect of magnetic field on critical heat flux of ferrofluid flow boiling in a vertical annulus. Experimental thermal and fluid science, 58, 156-169. https://doi.org/10.1016/j.expthermflusci.2014.06.023

59. Peng, H., Ding, G., Jiang, W., Hu, H., \& Gao, Y. (2009). Heat transfer characteristics of refrigerant-based nanofluid flow boiling inside a horizontal smooth tube. International Journal of Refrigeration, 32(6), 1259 1270. https://doi.org/10.1016/j.ijrefrig.2009.01.025

60. Nikkhah, V., Sarafraz, M. M., \& Hormozi, F. (2015). Application of spherical copper oxide (II) water nanofluid as a potential coolant in a boiling annular heat exchanger. Chemical and biochemical engineering quarterly, 29(3), 405-415. https://doi.org/10.15255/CABEQ.2014.2069

61. Afrand, M., Abedini, E., \& Teimouri, H. (2017). Experimental investigation and simulation of flow boiling of nanofluids in different flow directions. Physica E: Low-dimensional Systems and Nanostructures, 87, 248-253. https://doi.org/10.1016/j.physe.2016.10.026

62. Kim, S. J., McKrell, T., Buongiorno, J., \& Hu, L. W. (2010). Subcooled flow boiling heat transfer of dilute alumina, zinc oxide, and diamond nanofluids at atmospheric pressure. Nuclear Engineering and Design, 240(5), 1186-1194. https://doi.org/10.1016/j.nucengdes.2010.01.020

63. Lee, S. W., Park, S. D., Kang, S. R., Kim, S. M., Seo, H., Lee, D. W., \& Bang, I. C. (2012). Critical heat flux enhancement in flow boiling of $\mathrm{Al}_{2} \mathrm{O}_{3}$ and $\mathrm{SiC}$ nanofluids under low pressure and low flow conditions. Nuclear Engineering and Technology, 44(4), 429-436. http://dx.doi.org/10.5516/NET.04.2012.516

64. Suresh, S., Venkitaraj, K. P., Selvakumar, P., \& Chandrasekar, M. (2011). Synthesis of Al2O3-Cu/water hybrid nanofluids using two step method and its thermo physical properties. Colloids and Surfaces A: Physicochemical and Engineering Aspects, 388(1-3), 41-48. https://doi.org/10.1016/j.colsurfa.2011.08.005

65. Lee, T., Lee, J. H., \& Jeong, Y. H. (2013). Flow boiling critical heat flux characteristics of magnetic nanofluid at atmospheric pressure and low mass flux conditions. International Journal of Heat and Mass Transfer, 56(1-2), 101-106. https://doi.org/10.1016/j.ijheatmasstransfer.2012.09.030

66. Sarafraz, M. M., \& Hormozi, F. (2016). Comparatively experimental study on the boiling thermal performance of metal oxide and multi-walled carbon nanotube nanofluids. Powder Technology, 287, 412-430. https://doi.org/10.1016/j.powtec.2015.10.022

67. Wang, Y., Deng, K. H., Liu, B., Wu, J. M., \& Su, G. H. (2017). A correlation of nanofluid flow boiling heat transfer based on the experimental results of $\mathrm{AIN} / \mathrm{H} 2 \mathrm{O}$ and $\mathrm{Al} 2 \mathrm{O} 3 / \mathrm{H} 2 \mathrm{O}$ nanofluid. Experimental Thermal and Fluid Science, 80, 376-383. https://doi.org/10.1016/j.expthermflusci.2016.08.020

68. Henderson, K., Park, Y. G., Liu, L., \& Jacobi, A. M. (2010). Flow-boiling heat transfer of R-134a-based nanofluids in a horizontal tube. International Journal of Heat and Mass Transfer, 53(5-6), 944-951. https://doi.org/10.1016/j.ijheatmasstransfer.2009.11.026

69. Barber, J., Brutin, D., \& Tadrist, L. (2011). A review on boiling heat transfer enhancement with nanofluids. Nanoscale research letters, 6(1), 1-16. https://doi.org/10.1186/1556-276X-6-280

70. Kamel, M. S., \& Lezsovits, F. (2019). Boiling heat transfer of nanofluids: A review of recent studies. Thermal Science, 23(1), 109-124.Thermal Science, 23(1), 109-124. https://doi.org/10.2298/TSC1170419216K

71. Yao, S., \& Teng, Z. (2019). Effect of Nanofluids on Boiling Heat Transfer Performance. Applied Sciences, 9(14), 2818. https://doi.org/10.3390/app9142818

72. Kadam, M. T. V., and Bhat, D. M. A. (2017). Review paper on enhancement of heat transfer by using binary nanofluids. International Research Journal of Engineering and Technology (IRJET), 4(2). 
73. Kamel, M. S., Lezsovits, F., \& Hussein, A. K. (2019). Experimental studies of flow boiling heat transfer by using nanofluids. Journal of Thermal Analysis and Calorimetry, 138(6), 4019-4043. https://doi.org/10.1007/s10973-019-083332(0123456789().,-volV)(0123456789,-().volV)

74. Musa, S.M. (2015). Nanoscale Flow Advances, Modeling, and Applications. CRC Press Taylor and Francis Group.

75. Das, S. K., Putra, N., \& Roetzel, W. (2003). Pool boiling characteristics of nano-fluids. International journal of heat and mass transfer, 46(5), 851-862. https://doi.org/10.1016/S0017-9310(02)00348-4

76. Das, S. K., Putra, N., \& Roetzel, W. (2003). Pool boiling of nano-fluids on horizontal narrow tubes. International Journal of Multiphase Flow, 29(8), 1237-1247. https://doi.org/10.1016/S03019322(03)00105-8

77. Wen, D. (2012). Influence of nanoparticles on boiling heat transfer. Applied thermal engineering, 41, 2-9. https://doi.org/10.1016/j.applthermaleng.2011.08.035

78. Shahmoradi, Z., Etesami, N., \& Esfahany, M. N. (2013). Pool boiling characteristics of nanofluid on flat plate based on heater surface analysis. International Communications in Heat and Mass Transfer, 47, 113-120. https://doi.org/10.1016/j.icheatmasstransfer.2013.06.006

79. Sarafraz, M. M., \& Hormozi, F. (2014). Nucleate pool boiling heat transfer characteristics of dilute Al2O3ethyleneglycol nanofluids. International Communications in Heat and Mass Transfer, 58, 96-104. https://doi.org/10.1016/j.icheatmasstransfer.2014.08.028

80. Abdollahi, A., Salimpour, M. R., \& Etesami, N. (2017). Experimental analysis of magnetic field effect on the pool boiling heat transfer of a ferrofluid. Applied Thermal Engineering, 111, 1101-1110. https://doi.org/10.1016/j.applthermaleng.2016.10.019

81. Trisaksri, V., \& Wongwises, S. (2009). Nucleate pool boiling heat transfer of TiO2-R141b nanofluids. International Journal of Heat and Mass Transfer, 52(5-6), 1582-1588. https://doi.org/10.1016/j.ijheatmasstransfer.2008.07.041

82. Suriyawong, A., \& Wongwises, S. (2010). Nucleate pool boiling heat transfer characteristics of TiO2-water nanofluids at very low concentrations. Experimental Thermal and Fluid Science, 34(8), 992-999. https://doi.org/10.1016/j.expthermflusci.2010.03.002

83. Ali, H. M., Generous, M. M., Ahmad, F., \& Irfan, M. (2017). Experimental investigation of nucleate pool boiling heat transfer enhancement of TiO2-water based nanofluids. Applied Thermal Engineering, 113, 1146-1151. https://doi.org/10.1016/j.applthermaleng.2016.11.127

84. He, Y., Li, H., Hu, Y., Wang, X., \& Zhu, J. (2016). Boiling heat transfer characteristics of ethylene glycol and water mixture based $\mathrm{ZnO}$ nanofluids in a cylindrical vessel. International Journal of Heat and Mass Transfer, 98, 611-615. https://doi.org/10.1016/j.ijheatmasstransfer.2016.03.052

85. Chopkar, M., Das, A. K., Manna, I., \& Das, P. K. (2008). Pool boiling heat transfer characteristics of ZrO $2-$ water nanofluids from a flat surface in a pool. Heat and Mass Transfer, 44(8), 999-1004. https://doi.org/10.1007/s00231-007-0345-5

86. Sarafraz, M. M., \& Hormozi, F. (2015). Pool boiling heat transfer to dilute copper oxide aqueous nanofluids. International Journal of Thermal Sciences, 90, 224-237. https://doi.org/10.1016/j.ijthermalsci.2014.12.014

87. Liu, Z. H., Yang, X. F., \& Xiong, J. G. (2010). Boiling characteristics of carbon nanotube suspensions under subatmospheric pressures. International Journal of Thermal Sciences, 49(7), 1156-1164. https://doi.org/10.1016/j.ijthermalsci.2010.01.023

88. Kim, J. M., Kim, T., Kim, J., Kim, M. H., \& Ahn, H. S. (2014). Effect of a graphene oxide coating layer on critical heat flux enhancement under pool boiling. International Journal of Heat and Mass Transfer, 77, 919. 927. https://doi.org/10.1016/j.ijheatmasstransfer.2014.06.017

89. Kim, S. J., Bang, I. C., Buongiorno, J., \& Hu, L. W. (2006). Effects of nanoparticle deposition on surface wettability influencing boiling heat transfer in nanofluids. Applied Physics Letters, 89(15), 153107. https://doi.org/10.1063/1.2360892

90. Ding, Y., Chen, H., Wang, L., Yang, C. Y., He, Y., Yang, W., ... \& Huo, R. (2007). Heat transfer intensification using nanofluids. KONA Powder and Particle Journal, 25, 23-38. https://doi.org/10.14356/kona.2007006

91. Kim, H., Ahn, H. S., \& Kim, M. H. (2010). On the mechanism of pool boiling critical heat flux enhancement in nanofluids. Journal of Heat Transfer, 132(6). https://doi.org/10.1115/1.4000746

92. Liu, Z. H., \& Liao, L. (2008). Sorption and agglutination phenomenon of nanofluids on a plain heating surface during pool boiling. International Journal of Heat and Mass Transfer, 51(9-10), 2593-2602. https://doi.org/10.1016/j.ijheatmasstransfer.2006.11.050

93. Kiyomura, I. S., Manetti, L. L., Da Cunha, A. P., Ribatski, G., \& Cardoso, E. M. (2017). An analysis of the effects of nanoparticles deposition on characteristics of the heating surface and $\mathrm{ON}$ pool boiling of water. International Journal of Heat and Mass Transfer, 106, 666-674. https://doi.org/10.1016/j.ijheatmasstransfer.2016.09.051. 
94. Faulkner, D., Khotan, M., \& Shekarriz, R. (2003, March). Practical design of a $1000 \mathrm{~W} / \mathrm{cm} / \mathrm{sup} 2 /$ cooling system [high power electronics]. In Ninteenth Annual IEEE Semiconductor Thermal Measurement and Management Symposium, 2003. (pp. 223-230). IEEE. DOI: 10.1109/STHERM.2003.1194366

95. Lee, S. W., Kim, K. M., \& Bang, I. C. (2013). Study on flow boiling critical heat flux enhancement of graphene oxide/water nanofluid. International Journal of Heat and Mass Transfer, 65, 348-356. https://doi.org/10.1016/j.ijheatmasstransfer.2013.06.013

96. Heris, S. Z., Esfahany, M. N., \& Etemad, S. G. (2007). Experimental investigation of convective heat transfer of $\mathrm{Al} 2 \mathrm{O} 3 /$ water nanofluid in circular tube. International journal of heat and fluid flow, 28(2), 203-210. DOI: 10.1016/j.ijheatfluidflow.2006.05.001

97. Mansour, R. B., Galanis, N., \& Nguyen, C. T. (2011). Experimental study of mixed convection with water$\mathrm{Al} 2 \mathrm{O} 3$ nanofluid in inclined tube with uniform wall heat flux. International Journal of Thermal Sciences, 50(3), 403-410. https://doi.org/10.1016/j.ijthermalsci.2010.03.016

98. Fang, X., Wang, R., Chen, W., Zhang, H., \& Ma, C. (2015). A review of flow boiling heat transfer of nanofluids. Applied Thermal 1003-1017. https://doi.org/10.1016/j.applthermaleng.2015.08.100

99. Mahbubul, I. M., Saidur, R., \& Amalina, M. A. (2013). Heat transfer and pressure drop characteristics of Al2O3R141b nanorefrigerant in horizontal smooth circular tube. Procedia Engineering, 56, 323-329. doi: 10.1016/j.proeng.2013.03.126

100. Sarafraz, M. M., \& Hormozi, F. (2014). Forced convective and nucleate flow boiling heat transfer to alumnia nanofluids. Periodica Polytechnica Chemical Engineering, 58(1), 37-46. https://doi.org/10.3311/PPch.2206

101. Moreira, T. A., Nascimento, F. J., \& Ribatski, G. (2015, April). Flow boiling of nanofluids of water and Al2O3 inside a $1.1 \mathrm{~mm}$ round channel. In 9th International Conference on Boiling and Condensation Heat Transfer, Boulder, CO. https://doi.org/10.1115/ICNMM2015-48317

102. Setoodeh, H., Keshavarz, A., Ghasemian, A., \& Nasouhi, A. (2015). Subcooled flow boiling of alumina/water nanofluid in a channel with a hot spot: An experimental study. Applied Thermal Engineering, 90, 384-394. https://doi.org/10.1016/j.applthermaleng.2015.07.016

103. Yu, L., Sur, A., \& Liu, D. (2015). Flow boiling heat transfer and two-phase flow instability of nanofluids in a minichannel. Journal of Heat Transfer, 137(5). https://doi.org/10.1115/1.4029647

104. Paul, G., Das, P. K., \& Manna, I. (2016). Assessment of the process of boiling heat transfer during rewetting of a vertical tube bottom flooded by alumina nanofluid. International Journal of Heat and Mass Transfer, 94, 390-402. https://doi.org/10.1016/j.ijheatmasstransfer.2015.11.013

105. Salari, E., Peyghambarzadeh, M., Sarafraz, M., \& Hormozi, F. (2016). Boiling heat transfer of alumina nanofluids: role of nanoparticle deposition on the boiling heat transfer coefficient. DOI http://dx.doi.org/10.3311/PPch.9324

106. Zangeneh, A., Vatani, A., Fakhroeian, Z., \& Peyghambarzadeh, S. M. (2016). Experimental study of forced convection and subcooled flow boiling heat transfer in a vertical annulus using different novel functionalized $\mathrm{ZnO}$ nanoparticles. Applied Thermal $\quad$ Engineering, 109, https://doi.org/10.1016/j.applthermaleng.2016.08.056

107. Lee, T., Kam, D. H., Lee, J. H., \& Jeong, Y. H. (2014). Effects of two-phase flow conditions on flow boiling $\mathrm{CHF}$ enhancement of magnetite-water nanofluids. International Journal of Heat and Mass Transfer, 74, 278284. https://doi.org/10.1016/j.ijheatmasstransfer.2014.03.028

108. Peng, H., Ding, G., Jiang, W., Hu, H., \& Gao, Y. (2009). Measurement and correlation of frictional pressure drop of refrigerant-based nanofluid flow boiling inside a horizontal smooth tube. International Journal of Refrigeration, 32(7), 1756-1764. https://doi.org/10.1016/j.ijrefrig.2009.06.005

109. Sarafraz, M. M., Hormozi, F., Peyghambarzadeh, S. M., \& Vaeli, N. (2015). Upward Flow Boiling to DI-Water and Cuo Nanofluids Inside the Concentric Annuli. Journal of Applied Fluid Mechanics, 8(4).

110. Abedini, E., Behzadmehr, A., Sarvari, S. M. H., \& Mansouri, S. H. (2013). Numerical investigation of subcooled flow boiling of a nanofluid. International Journal of Thermal Sciences, 64, 232-239. https://doi.org/10.1016/j.ijthermalsci.2012.08.008

111. Ciloglu, D., \& Bolukbasi, A. (2015). A comprehensive review on pool boiling of nanofluids. Applied Thermal Engineering, 84, 45-63. https://doi.org/10.1016/j.applthermaleng.2015.03.063

112. Seon Ahn, H., \& Hwan Kim, M. (2012). A review on critical heat flux enhancement with nanofluids and surface modification. Journal of Heat transfer, 134(2). https://doi.org/10.1115/1.4005065

113. Murshed, S. S., De Castro, C. N., Lourenço, M. J. V., Lopes, M. L. M., \& Santos, F. J. V. (2011). A review of boiling and convective heat transfer with nanofluids. Renewable and Sustainable Energy Reviews, 15(5), 2342-2354. https://doi.org/10.1016/j.rser.2011.02.016 